Finance and Economics Discussion Series Divisions of Research \& Statistics and Monetary Affairs Federal Reserve Board, Washington, D.C.

\title{
Reserve Requirement Systems in OECD Countries
}

\author{
Yueh-Yun C. OBrien
}

2007-54

NOTE: Staff working papers in the Finance and Economics Discussion Series (FEDS) are preliminary materials circulated to stimulate discussion and critical comment. The analysis and conclusions set forth are those of the authors and do not indicate concurrence by other members of the research staff or the Board of Governors. References in publications to the Finance and Economics Discussion Series (other than acknowledgement) should be cleared with the author(s) to protect the tentative character of these papers. 


\title{
Reserve Requirement Systems in OECD Countries
}

\author{
Yueh-Yun C. O’Brien \\ July 23, 2007 \\ Division of Monetary Affairs \\ Board of Governors of the Federal Reserve System \\ Washington, D.C. 20551 U.S.A. \\ (E-mail: m1yco00@frb.gov)
}

I am grateful to Brian Madigan, Board of Governors of the Federal Reserve System, for his careful review and valuable comments on this and earlier drafts. I also thank Faruk Kavak, the Central Bank of the Republic of Turkey, for his helpful comments on required reserve system in Turkey. The author is responsible for any errors in the paper. The analysis and conclusions set forth are those of the author and do not indicate concurrence by other members of the research staff or the Board of Governors of the Federal Reserve System. 


\title{
Reserve Requirement Systems in OECD Countries
}

\author{
Yueh-Yun C. O’Brien
}

\begin{abstract}
This paper compares the reserve requirements of OECD countries. Reserve requirements are the minimum percentages or amounts of liabilities that depository institutions are required to keep in cash or as deposits with their central banks. To facilitate monetary policy implementation, twenty-four of the thirty OECD countries impose reserve requirements to influence their banking systems' demand for liquidity. These include twelve OECD countries that are also members of the European Economic and Monetary Union (EMU) and twelve nonEMU OECD countries. All EMU countries employ a single reserve requirement system, which is treated as one entity.

The reserve requirement system for each of the twelve non-EMU OECD countries is discussed separately. The similarities and differences among the thirteen reserve requirement systems are highlighted. The features of reserve requirements covered include: reservable liabilities, required reserve ratios, reserve computation periods, reserve maintenance periods, types of reserve requirements, calculations of required reserves, eligible assets for satisfying reserve requirements, remuneration on reserve balances, non-compliance penalties, carry-over of reserve balances, and required clearing balances.
\end{abstract}

Key words: reservable liabilities, required reserve ratios, reserve computation periods, reserve maintenance periods, lagged reserve requirements, remuneration.

JEL classifications: E4, E5 


\section{Introduction}

Central banks by definition are the sole issuers of "central bank money," which consists of banknotes and deposit balances held by depository institutions at central banks. This feature provides them the power to implement monetary policy by influencing liquidity in their banking systems in order to achieve their policy (interest rate) targets and thus promote their long-term objectives. ${ }^{1}$ Central banks use various tools to affect the demand for and the supply of liquidity in the banking system. As shown in the following figure, three tools are typically used by central banks in the implementation of policy: reserve requirement systems, open market operations, and standing facilities. The first tool is used to affect the demand for liquidity in the banking system, while the other two are used to adjust the supply of liquidity. These tools enable a central bank to affect the aggregate deposit balances in all depository institutions' accounts with the central bank. When a central bank intends to raise (lower) its overnight interest target rate or if the overnight market rates are below (above) the target rate, it reduces (increases) the supply of aggregate deposit balances in the banking system relative to the demand to bring the overnight market rate near the desired levels.

Reserve requirements are the minimum percentages or amounts of liabilities that depository institutions are required to keep on hand in cash (vault cash) or as deposits with their central banks (required reserve balances). Changing reserve requirements changes demand for liquidity in the banking system. In practice, reserve requirements are changed infrequently. Some central banks remunerate depository institutions on required reserve balances, while a penalty is normally assessed on non-compliance with reserve requirements.

Open market operations are the main tool used by central banks to align the supply of liquidity in the banking systems with the demand at an interest rate close to the target rate. When the overnight interest rate is above (below) the target rate, the central bank injects (drains) liquidity. Standing facilities make credit available to depository institutions, to cover possible daylight and/or overnight overdrafts on their central bank accounts and usually carry interest rate charges. Standing facilities may also be used to absorb liquidity and may provide a floor below the overnight interest rate.

\footnotetext{
${ }^{1}$ A banking system is defined to consist of all depository institutions, credit institutions and/or financial institutions in a country that can establish deposit accounts at their central bank. These institutions are referred as banks, credit institutions, or depository institutions through the paper.
} 


\section{Figure}

\section{Policy Tools Typically Used in Monetary Policy Implementation}

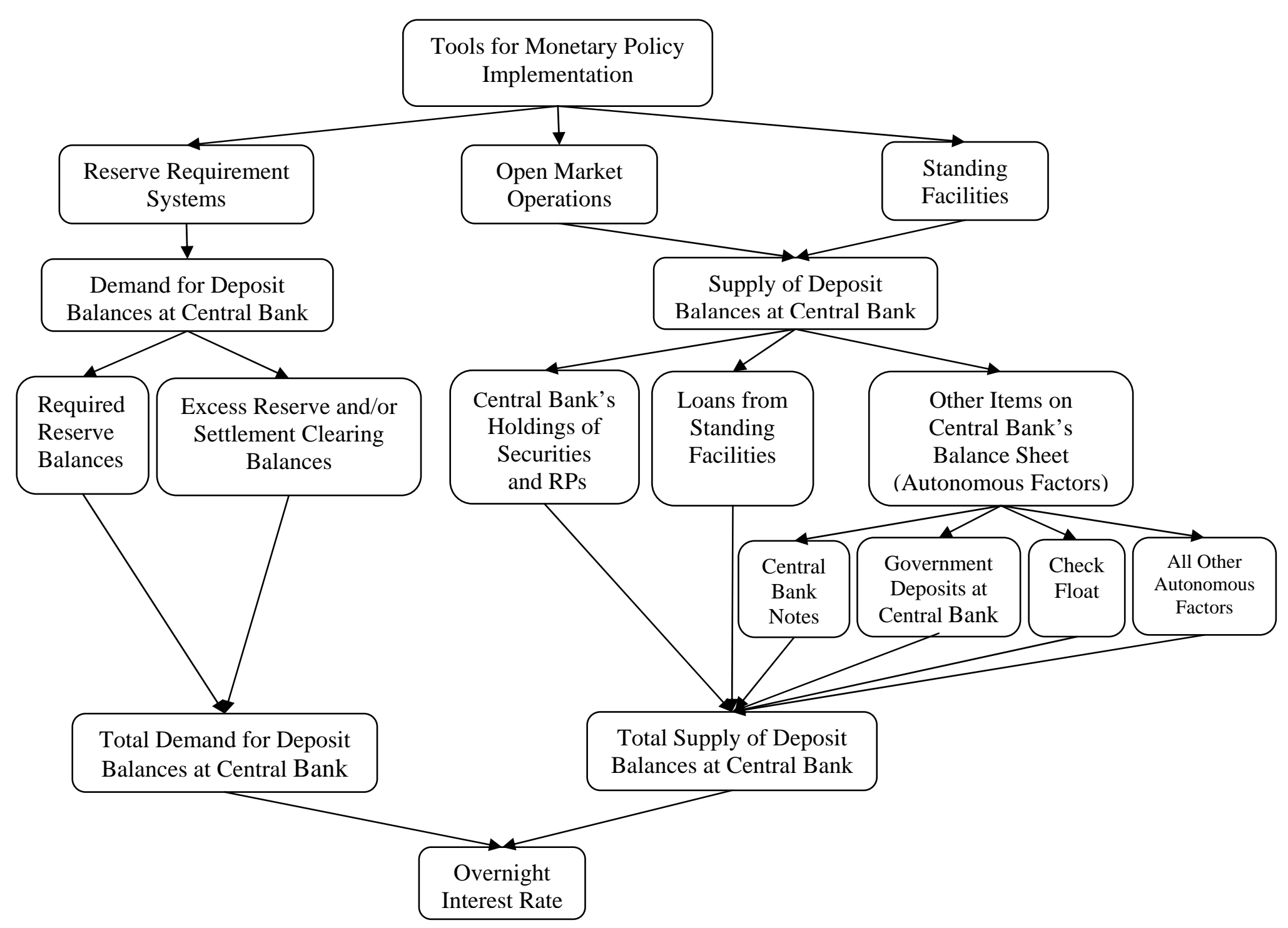


Twenty-four of the thirty countries that belong to the Organization for Economic Cooperation and Development (OECD) employ reserve requirement systems. These include twelve OECD countries that are also members of the European Economic and Monetary Union (EMU) ${ }^{2}$ and twelve non-EMU OECD countries. ${ }^{3}$ A single reserve requirement system is employed by all EMU countries; that system is discussed as one entity. The reserve requirement systems in the other twelve countries are discussed separately. This paper reviews the main features of the thirteen reserve requirement systems and highlights their similarities and differences. The remaining six OECD countries implement monetary policy without reserve requirements. ${ }^{4}$ As this paper focuses on reserve requirement systems, their approaches to monetary policy implementation are not covered.

The paper is organized as follows: In the next section, background on reserve requirement systems is presented. The third section highlights similarities and differences among the main features of the thirteen reserve requirement systems in OECD countries. The final section presents a summary of the main features of each reserve requirement system. In the appendix, tables are provided for the important features of the individual reserve requirement systems.

\section{Background on Reserve Requirement Systems}

To provide some background on reserve requirement systems, this section discusses the major characteristics of reserve requirement systems:

\footnotetext{
${ }^{2}$ The EMU, called the euro area, adopted a single currency (the euro) in January 1999. It comprises fourteen members of the twenty-seven European Union countries. Twelve of them are also OECD members: Austria, Belgium, Finland, France, Germany, Greece, Ireland, Italy, Luxembourg, Netherlands, Portugal, and Spain. The European Union finance ministers made Slovenia the thirteenth member of the EMU in July 2006. Slovenia and Lithuania officially adopted the euro on January 1, 2007. Neither is a member of the OECD. Slovakia will adopt the euro on January 1, 2009. It is a member of OECD and the exchange rate mechanism II (ERMII), as well as Denmark. Members of ERMII link their currencies to the euro but are not currently adopting the euro.

${ }^{3}$ These twelve countries include Czech Republic, Hungary, Iceland, Japan, Korea, Mexico, Poland, Slovakia, Switzerland, Turkey, the United Kingdom, and the United States.

${ }^{4}$ The six countries consist of Australia, Canada, Denmark, New Zealand, Norway, and Sweden. The central banks of these six countries make interbank payment settlement accounts available to depository institutions subject to certain rules. They provide standing facilities with interest charges and the lending interest rate sets an upper bound on the market interest rate. These central banks also pay interest on end-of-day account surpluses, and that interest rate forms a lower bound on the market rate Thus, lending and deposit rates form a corridor for the target overnight interest rate.

In addition to imposing rules for settlement accounts and providing standing facilities, most of these central banks influence the aggregated settlement balances in the banking systems mainly through open market operations. The liquidity policy of most of these central banks aims at either a zero surplus settlement balance or a small positive level if there is demand for excess settlement balances, such as in Canada.
} 


\section{Reservable liabilities}

Reservable liabilities are depository institutions' liabilities that are subject to reserve requirements. ${ }^{5}$ The reserve base is the average of a depository institution's reservable liabilities over a computation period that are subject to a positive required reserve ratio. ${ }^{6}$ The criteria used by OECD countries to determine whether a liability is reservable include: maturity, type of holder, type of liability, and currency denominations. In determining reservability, all countries classify liabilities by type of holder - for example, persons, central banks, or other depository institutions. Most countries also classify them by liability type, such as deposits, loans, and debt securities. Some also classify them by maturity and/or currency denomination. Typically, liquid liabilities are subject to reserve requirements. Some countries exempt foreign-currency-denominated liabilities from reserve requirements.

\section{Required reserve ratios}

Required reserve ratios (RRRs) are the minimum percentages of reservable liabilities that depository institutions must hold to meet reserve requirements. At present, marginal required reserve ratios in most countries are no more than 5 percent.

Various criteria are used by central banks to set RRRs. Some vary RRRs based on one or two criteria while others use many criteria. The prevailing criteria may be summarized as follows:

(1) Types of deposits or liability’s liquidity - Highly liquid deposits tend to be subject to higher RRRs than less liquid deposits, as in Japan, Korea, and the United States.

(2) Amount of reservable liabilities - Marginal RRRs tend to vary positively with the amount of a depository institution's reservable liabilities, as in Japan and the United States.

(3) Maturity of liabilities - Liabilities with a short-term maturity tend to be subject to higher RRRs than those with a longer-term maturity, as in the EMU, Czech Republic, Hungary, Iceland, Poland, and Slovakia, all of which impose positive RRRs only on liabilities with a maturity up to two years.

(4) Currency denominations of liabilities - RRRs on foreign-currency denominated liabilities are lower in some countries but higher in other countries.

\footnotetext{
${ }^{5}$ Some reservable liabilities may have a zero required reserve ratio, at least at times.

6 "Reserve base", referring to a base used to compute required reserves in a computation period, is a term frequently used in EMU and other European countries.
} 
(5) Types of deposit holders - RRRs may vary with holder type (for instance, nonpersonal, resident, or other depository institution). Some countries classify liabilities due to other depository institutions as non-reservable. The United States subjected non-personal savings and time deposits to positive RRRs until that ratio was reduced to zero in early 1991; it has excluded personal savings and time deposits from reservable liabilities since October 6, 1983. Japan and Korea subject foreigncurrency deposits held by non-residents to lower RRRs than those held by residents.

(6) Character or business of depository institutions - Japan has lower RRRs for deposits at Norinchukin Bank than deposits at other types of depository institutions. ${ }^{7}$

\section{Reserve computation periods}

A computation period (CP) consists of the days for which reservable liabilities are used to calculate required reserves. The CP may consist of either a single day or multiple days. A single-day CP is usually set at the last day of either a calendar month or quarter. ${ }^{8}$ A multiday CP may comprise a number of consecutive calendar days or multiple end-dates of consecutive calendar months or quarters. A multi-day CP increases the cost and difficulty of a depository institution's attempts to reduce reserve requirements by manipulating its reservable liabilities. However, data reporting and processing expenses for both depository institutions and the central bank increase with data reporting frequency in a CP. The relative importance that a central bank places on guarding against reserve avoidance versus the costs of reporting and processing data can affect the central bank's decision on the length of a CP. The length of a CP ranges from one day to one month among the OECD countries (see table below).

\section{Reserve maintenance periods}

A maintenance period (MP) consists of the days for which a depository institution's endof-day reserve balances are used to determine whether it fulfills its reserve requirement. A multi-day MP with a reserve-averaging provision can benefit the central bank in managing

\footnotetext{
${ }^{7}$ Norinchukin Bank is a cooperative bank owned by over 5,000 agricultural, forestry and fishery cooperatives nationwide. Most of the bank's deposits come from these cooperatives, which the bank uses for investments, disbursing proceeds, and loans to its member cooperatives. It has acted as a full-scale commercial bank since the Japanese government rewrote the bank's charter in 1986. It has become a financial holding company in the United States since December 18, 2006. It has branches and financial investment offices in Tokyo, Beijing, London, and Zurich.

${ }^{8}$ Turkey's single-day CP is on Friday in every other week, which is also the first day of the fourteen-day MP associated with the previous $\mathrm{CP}$.
} 
the liquidity in the banking system and also the depository institutions' management of their own liquidity. ${ }^{9}$ In particular, when a MP lags its associated CP, the central bank knows, ex ante, the aggregate reserve balances that depository institutions need to hold over the MP. Individual depository institutions also know their own average required reserve balances to be met for the MP. Depository institutions can thus vary their reserve holdings from day to day during the MP according to their liquidity situation so as to provide a buffer to absorb unexpected payment inflows or outflows. A multi-day MP with an averaging provision can have additional benefits, which will be discussed in section II.7 below. All thirteen reserve requirement systems have multi-day MPs, ranging from two to five weeks.

\section{Types of reserve requirement systems}

The type of reserve requirement system is determined by how much a MP and its associated CP overlap. Reserve requirement systems can generally be classified into three types: (1) lagged reserve requirement systems (LRR) with MPs starting after the end of the associated CPs; (2) semi-lagged reserve requirement systems (semi-LRR) with MPs starting roughly in the middle of the associated CPs; and (3) contemporaneous reserve requirement systems (CRR) with MPs completely or mostly overlapping the associated CPs.

The ability of a central bank to hit its monetary policy interest rate target depends in part on the availability of good information on the banking system's net liquidity position - the supply of versus the demand for reserve balances. This information provides an ex ante basis for the assessment of the need for open market operations. As described above, a lag between a CP and its associated MP is helpful in providing advance information on the demand for required reserves and can also benefit depository institutions' liquidity management. Under LRR, advance information regarding the demand for required reserves is available before the start of each MP. Under semi-LRR, the liquidity need for reserve requirements is known in the middle of a MP. For this reason, all OECD countries with reserve requirement systems employ LRR, except Korea which uses semi-LRR.

Despite this advantage of LRR, the Federal Reserve switched from LRR to CRR on February 2, 1984. The decision to shift to CRR, made on October 5, 1982, reflected the Federal Reserve's intention to tighten and speed up the response of reserve conditions to

\footnotetext{
${ }^{9}$ The OECD countries with reserve requirement systems all adopt reserve-averaging schemes for reserve maintenance.
} 
deviations of M1 growth from its target path, consistent with the nonborrowed reserves operating procedure that had been employed since October 1979. Under CRR, the fourteenday MP (starting on Thursday) for transaction deposits lagged its associated fourteen-day CP (starting on Tuesday) by two days. ${ }^{10}$ Moreover, after the decision to implement CRR, the Federal Reserve replaced M1 with M2 as the primary intermediate monetary target in the fall of 1982 and shifted away from its nonborrowed reserves operating procedure. ${ }^{11}$ In subsequent years, it gradually reduced the weight accorded to the monetary aggregates in the conduct of policy, providing one motivation for moving away from CRR. Furthermore, under CRR, the demand for required reserves in the United States was not known until the end of each MP. This uncertainty increased the difficulty for the Federal Reserve in hitting its rate target and may have raised the volatility of the federal funds rate. ${ }^{12}$ With reduced emphasis on the aggregates in conducting policy, and given the shift away from a reservesoriented operating procedure, there was little advantage to maintaining a CRR system. As a consequence of these developments, the Federal Reserve switched back to LRR in the MP beginning July 30, 1998.

${ }^{10}$ Required reserves for non-transaction deposits remained under LRR with a 17-day lag between a MP and its associated CP, but they accounted for a bit less than 25 percent of total required reserves.

${ }^{11}$ M1 was downgraded as the primary intermediate monetary target because of the erratic behavior of M1 demand relative to its primary determinants, likely resulting from the special promotion of newly introduced types of deposits, such as NOW, super NOW, and MMDAs in the early 1980s. At that time, transaction deposits were subject to a 12 percent reserve requirement, but only nonpersonal savings and certain nonpersonal time deposits among nontransaction components of M2 were subject to a 3 percent reserve requirement. Thus, the then-used nonborrowed reserves operating procedure had to be modified, since its automaticity deriving mainly from variations in required reserves on transaction deposits was not well suited for controlling M2.

Under the post-October 1982 procedure, as explained by Governor Wallich (1984), the Federal Reserve set an intended borrowing level as a policy decision at its monetary policy meeting. "This level of borrowing is then deducted from the total of required reserves consistent with the target path for money supply and an assumed level of excess reserves - in order to achieve an initial path for nonborrowed reserves. However, as money and reserve demands deviated from the trajectories set at the time of the policy meeting, the intended borrowing level is sought through adjustments to the initial nonborrowed-reserve path." In other words, "Since the fall of 1982, the nonborrowed reserve strategy and its automaticity have given way to a technique that allows the funds rate to be determined by the market, through the targeting of discount-window borrowing from one reserve-maintenance period to the next, implemented by allowing a flexible nonborrowed-reserve path..... In contrast, under the October 1979 procedure, borrowing was allowed to change consistent with the attainment of a nonborrowed-reserve path targeted for the entire intermeeting period."

12 For example, Hilton (2005) pointed out the difficulty for the Federal Reserve to estimate accurately reserve demand within a MP and the increase in volatility of the federal funds rate in the 1990s. The federal funds rate is the interest rates that depository institutions pay each other to borrow reserve balances. 


\section{The lag from a CP to its associated MP}

The advantages of a lag between a CP and its corresponding MP were described in the previous section. The length of the lag is usually determined by the time required for data reporting and processing. The lag for OECD countries ranges from one week to $2 \frac{1}{2} 2$ months.

\section{Calculations and maintenance of required reserves}

Required reserves are calculated based on reserve bases and their associated RRRs. Required reserves for a reserve base in a CP are equal to the product of the reserve base times its associated RRR. Total required reserves for a depository institution in a CP are calculated by aggregating required reserves across all reserve bases.

As discussed above, reserve-averaging provisions for reserve maintenance can benefit both the central bank and depository institutions. In addition to the advantages mentioned, an averaging scheme provides individual depository institutions an incentive to arbitrage expected changes in the overnight interest rate over a multi-day MP. When the overnight interest rate is high relative to the remuneration rate on required reserves or the expected overnight interest rate later in the MP, a depository institution may choose to reduce its reserve balances relative to its requirement. This would put downward pressure on the overnight rate. If the overnight rate is low, a depository institution may raise its reservebalance holding relative to its requirement, putting upward pressure on rates. This arbitrage behavior will reduce deviations between market rates and the overnight interest rate target within a MP and thus facilitate the implementation of monetary policy. ${ }^{13}$ All OECD countries with a reserve requirement scheme use a reserve-averaging regime over a multi-day MP.

\section{Eligible assets for satisfying required reserves}

All OECD countries with a reserve requirement scheme accept reserve balances at the central banks as eligible assets for satisfying reserve requirements. Three countries also count vault cash (VC) toward required reserves. ${ }^{14}$ Application of VC toward required

${ }^{13}$ Depository institutions' ability to conduct such arbitrage declines over time in a MP and vanishes at the end of a MP. Further, when expectations about the path of the overnight rate are volatile, a reserve-averaging provision can introduce a new source of instability in the demand for reserves. In particular, when market participants expect the central bank to change its interest rate target before the end of a MP, the "anticipation effect" causes the overnight rate to move toward the new target in the days ahead of the actual change. Indeed, Carpenter and Demiralp (2006) and Hilton (2005) documented evidence of such effect in the fed funds market of the United States.

${ }^{14}$ The three countries are Switzerland, the United States, and Korea. The first two countries count all VC, but Korea allows up to 35 percent of required reserves to be satisfied by VC. 
reserves can reduce depository institutions' holdings of reserve balances for reserve requirement purpose. Because VC is held to meet customers' needs, the application of VC toward required reserves is usually viewed as imposing no marginal cost to its holders. Hence, permitting the application of VC to required reserves lessens the burden of reserve requirements on depository institutions. However, it can complicate the task of central banks in monitoring reserve requirement compliance and can increase data reporting and processing costs. Furthermore, decreases in depository institutions' required reserve balances owing to the application of vault cash to reserve requirements tend to reduce depository institutions’ incentive or ability to arbitrage expected changes in overnight interest rates. As a result, the application of VC to reserve requirements may decrease the effectiveness of reserve requirements functioning as a buffer to absorb autonomous fluctuations in the market for reserves. This, in turn, could increase the volatility of overnight interest rates in a MP. ${ }^{15}$ As of January 2007, applied VC accounted for about 80 percent of total required reserves in the United States and required reserve balances accounted for only 20 percent. $^{16}$

\section{Carry-over and required clearing balances}

Carry-over and required clearing balances (RCBs) are two features related to reserve requirements employed only in the United States. The carry-over provision allows depository institutions to carry over some excess or deficiency of their required reserves in a MP to be used or made up only in the following MP (details provided in section IV.13.8 and Table 12 in the appendix). Carry-over eases depository institutions’ liquidity management by providing a cushion to partially offset unexpected payment flows, with the likely effect of reducing fluctuations of overnight interest rates. However, a carry-over allowance can complicate the central bank’s monitoring of compliance with reserve requirements.

A required clearing balance is a period-average amount that a depository institution may contract to maintain with a Federal Reserve Bank in addition to its required reserve balance. Required clearing balances are also called contractual clearing balances, which facilitate clearing of transactions drawn on depository institutions’ Federal Reserve accounts. RCBs

\footnotetext{
${ }^{15}$ For detailed discussion, see Clouse and Elmendorf (1997).

16 In the early 1990s, total required reserve balances accounted for nearly one-half of total required reserves. Since 1994, depository institutions, to reduce their required reserves, have swept their transaction deposits to nontransaction deposits which have been subject to a zero RRR since 1991. Indeed, many depository institutions with a positive reserve requirement have been able to completely satisfy their reserve requirements with their VC. As a consequence, total required reserve balances have steadily declined.
} 
boost reserve balances at the Federal Reserve System. Their maintenance requirements are integrated with those for required reserves. Their pre-commitment and period-averaging features give them the same predictability and arbitrage benefits for policy implementation as required reserve balances. Between 2003 and 2006, the average level of RCBs was approximately equal to the average level of required reserve balances.

Although a depository institution can adjust the level of a RCB prior to each MP, the RCB must be set before the start of the MP. The average of a depository institution's daily RCBs across the days in a MP needs to fall within its so-called clearing balance band. A depository institution's required clearing band is equal to its RCB plus or minus the greater of $\$ 25,000$ or 2 percent of the RCB. The average of actual daily RCBs in a MP, up to the top of the band, generates earnings credits which may be used to offset charges for eligible services provided by the Federal Reserve Banks. ${ }^{17}$ Total RCBs tend to move inversely with short-term market rates because interest rates applied on earning credits move in tandem with threemonth U.S. Treasury bill rates. For example, if short-term interest rates decline, depository institutions need more RCBs to earn sufficient credit to pay for a given amount of services. ${ }^{18}$ Thus, RCBs can yield similar advantages and disadvantages as those of carry-over described in the paragraph above.

In some ways, RCBs function like the voluntary reserve requirement system that is used in the United Kingdom. ${ }^{19}$ For example, both schemes are voluntary, require an advance setup in determining the pledged amounts before each MP with the amounts varying within specific bands from one MP to the next, and earn (explicit or implicit) interest for positive balances up to the top of the bands.

\section{Remuneration on reserve balances}

Reserve requirements may impose a burden on depository institutions that potentially includes (1) the opportunity cost of the interest-bearing liquid assets if required reserve balances are not remunerated at overnight market rates; (2) loss of liquidity of the funds tied

\footnotetext{
17 Interest rates applied on earnings credit are equal to the rolling 13-week average of the annualized coupon equivalent yield of 3-month U.S. Treasury bill rates in the secondary market with two adjustments (for details, see section IV.13.11). Earnings credit is calculated by multiplying the applicable interest rate by the average of daily RCBs in a MP, up to the top of the band. Charges for services that are not covered by earnings credits are paid through fees.

${ }^{18}$ Indeed, this occurred from 2001 to 2004 as discussed in Hilton (2005), when the target federal funds rate was steadily reduced from 6 percent to 1 percent.

${ }^{19}$ For details of the reserve requirements in the United Kingdom, see section IV.12 and Table 11 in the Appendix.
} 
Table

\section{Summary of Main Features of Reserve Requirement Systems In the EMU and 12 OECD Countries*}

\begin{tabular}{|c|c|c|c|c|c|c|c|c|c|c|c|c|c|c|}
\hline \multirow{2}{*}{ Country } & \multirow{2}{*}{$\begin{array}{l}\text { Type } \\
\text { of } \\
\text { RR }\end{array}$} & \multirow{2}{*}{$\begin{array}{c}\text { RRR } \\
(\%)\end{array}$} & \multirow{2}{*}{$\mathbf{C P}$} & \multirow{2}{*}{ MP } & \multirow{2}{*}{$\operatorname{Lag}^{1}$} & \multicolumn{2}{|c|}{$\begin{array}{c}\text { Period } \\
\text { Averaging }\end{array}$} & \multicolumn{2}{|c|}{$\begin{array}{r}\text { Eligible } \\
\text { Assets }\end{array}$} & \multirow{2}{*}{$\begin{array}{l}\text { Carry- } \\
\text { over } \\
\text { and } \\
\text { RCB } \\
\end{array}$} & \multicolumn{2}{|c|}{$\begin{array}{c}\text { Remuneration } \\
\text { rate }\end{array}$} & \multirow{2}{*}{$\begin{array}{l}\text { Penalty } \\
\text { Measure }\end{array}$} & \multirow{2}{*}{$\begin{array}{l}\text { Table } \\
\text { No. }\end{array}$} \\
\hline & & & & & & $\mathbf{C P}$ & MP & VC & $\mathbf{R B}$ & & $\mathbf{R R}$ & ER & & \\
\hline $\begin{array}{l}\text { Czech } \\
\text { Republic }\end{array}$ & LRR & $0 \& 2$ & 1 day & $\begin{array}{c}4-5 \\
\text { weeks }\end{array}$ & $\begin{array}{c}4-5 \\
\text { weeks }\end{array}$ & no & yes & no & yes & no & $\begin{array}{c}\text { 2-week } \\
\text { repo rate }\end{array}$ & no & $\begin{array}{c}200 \% \text { of } \\
\text { Lombard rate }\end{array}$ & 1 \\
\hline EMU & LRR & $0 \& 2$ & 1 day & $\begin{array}{c}3-5 \\
\text { weeks }^{3}\end{array}$ & $\begin{array}{l}1 \frac{1 / 2-21 / 2}{\text { months }} \\
\text { mons }\end{array}$ & No & yes & no & yes & no & $\begin{array}{c}\text { Average } \\
\text { of } \mathrm{Mr}^{4}{ }^{4} \\
\text { in a MP }\end{array}$ & no & $\begin{array}{l}5 \%+\mathrm{Mr}_{\mathrm{i}} \text { or } \\
200 \% \text { of } \mathrm{Mr}_{\mathrm{i}}{ }^{4} \\
\text { or hold } \\
\text { interest- free } \\
\text { dep. up } \\
\text { to } 300 \% \text { of } \\
\text { shortfall } \\
\end{array}$ & 2 \\
\hline Hungary & LRR & $0 \& 5$ & 1 day & 1 month & $\begin{array}{c}1 \\
\text { month }\end{array}$ & no & yes & no & yes & no & $\begin{array}{l}\text { Central } \\
\text { bank base } \\
\text { rate }\end{array}$ & no & $\begin{array}{c}\text { hold interest- } \\
\text { free deposits } \\
\text { at deficient } \\
\text { amount }\end{array}$ & 3 \\
\hline Iceland & LRR & $0 \& 2$ & $\begin{array}{l}2 \\
\text { month- } \\
\text { end } \\
\text { dates }\end{array}$ & 1 month & $\begin{array}{c}21 \\
\text { days }^{5}\end{array}$ & yes & yes & no & yes & no & $\begin{array}{c}\text { rate on RR } \\
\text { set by CBI } \\
\text { above } \\
\text { current } \\
\text { account }^{\text {rate }} \\
\text { rate }^{6} \\
\end{array}$ & $\begin{array}{l}\text { Curr.- } \\
\text { acct. } \\
\text { Rate }^{6}\end{array}$ & $\begin{array}{c}\text { Penalty } \\
\text { decided by } \\
\mathrm{CBI}^{6}\end{array}$ & 4 \\
\hline Japan & LRR & $\begin{array}{c}0.05- \\
1.3^{7} \\
\end{array}$ & $\begin{array}{c}1 \\
\text { month }\end{array}$ & 1 month & $\begin{array}{c}1 \frac{1 / 2}{2} \\
\text { months }\end{array}$ & yes & yes & no & yes & no & no & no & $\begin{array}{c}3.75 \%+ \\
\text { discount rate }^{8}\end{array}$ & 5 \\
\hline Korea & $\begin{array}{l}\text { Semi- } \\
\text { LRR }\end{array}$ & $1-5^{10}$ & $\begin{array}{c}1 / 2 \\
\text { month }\end{array}$ & $1 / 2$ month & 7 days & yes & yes & $\begin{array}{l}\text { Up to } \\
35 \%\end{array}$ & \begin{tabular}{|l} 
At \\
least \\
$65 \%$ \\
\end{tabular} & no & no & no & $1 \%^{9}$ & 6 \\
\hline Mexico & Zarr $^{11}$ & & & 28 days & & & yes & & & & no & no & $\begin{array}{l}\text { 200\% 28-day } \\
\text { CETES rate }^{12}\end{array}$ & \\
\hline Poland & LRR & $0 \& 3.5$ & 1 day & 1 month & $\begin{array}{c}1 \\
\text { month }\end{array}$ & no & yes & no & yes & no & $\begin{array}{l}90 \% \text { of } \\
\text { rediscount } \\
\text { rate }^{13}\end{array}$ & no & $\begin{array}{c}\text { rate set by } \\
\text { NBP, up to } \\
\text { double Lomb. } \\
\text { rate }^{14}\end{array}$ & 7 \\
\hline Slovakia & LRR & 2 & 1 day & 1 month & $\begin{array}{c}1 \\
\text { month }\end{array}$ & no & yes & no & yes & no & $1.5 \%$ & no & $5 \%$ over $\mathrm{Mr}^{3}$ & 8 \\
\hline Switzerland & LRR & 2.5 & $\begin{array}{c}3 \\
\text { month- } \\
\text { end } \\
\text { dates } \\
\end{array}$ & 1 month & $\begin{array}{c}20 \\
\text { days }^{5}\end{array}$ & yes & yes & $\begin{array}{l}\text { Up to } \\
100 \%\end{array}$ & yes & no & no & no & $\begin{array}{c}\text { 3\% over } \\
\text { 1-month } \\
\text { Libor in Swiss } \\
\text { deposits } \\
\end{array}$ & 9 \\
\hline Turkey & LRR & $\begin{array}{l}6 \& \\
11^{15}\end{array}$ & 1 day & 14 days & 14 days & no & yes & no & yes & no & $\begin{array}{c}75 \% \text { of } \\
\text { overnight } \\
\text { lending } \\
\text { rate }^{16} \\
\end{array}$ & no & $\begin{array}{l}\text { hold interest- } \\
\text { free dep. or } \\
150 \% \text { over } \\
\text { lending rate }{ }^{17} \\
\end{array}$ & 10 \\
\hline U. K. & & $\begin{array}{l}\text { Set by } \\
\text { banks }^{18}\end{array}$ & $\begin{array}{l}1 / 2 \text { year } \\
\text { for } \\
\text { target } \\
\text { ceiling } \\
\text { calc. }^{19}\end{array}$ & $\begin{array}{c}4-5 \\
\text { weeks }^{3}\end{array}$ & $\begin{array}{c}\text { reserve } \\
\text { target } \\
\text { set at } \\
\text { least } 2 \\
\text { days } \\
\text { ahead } \\
\text { MP } \\
\end{array}$ & yes & yes & no & yes & no & $\begin{array}{l}\text { the official } \\
\text { rate }(\mathrm{OR})^{20}\end{array}$ & $\begin{array}{l}\text { OR } \\
\text { up to } \\
\text { top of } \\
\text { target } \\
\text { band }\end{array}$ & $\begin{array}{l}\text { OR on excess } \\
\text { or shortfall of } \\
\text { RR over band; } \\
\text { double OR on } \\
\text { overdraft }^{21}\end{array}$ & 11 \\
\hline U. S. & LRR & $\begin{array}{l}0,3 \\
\& 10\end{array}$ & $\begin{array}{c}14 \\
\text { days }\end{array}$ & 14 days & 30 days & yes & yes & $\begin{array}{l}\text { Up to } \\
100 \%\end{array}$ & yes & yes & no & no & $\begin{array}{c}\% \text { over } \\
\text { primary credit } \\
\text { rate }\end{array}$ & 12 \\
\hline
\end{tabular}

*Glossary of abbreviations

CP: Reserve Computation Period.

LRR: Lagged Reserve Requirements.

RB: Reserve Balance.

RR: Reserve Requirements or Required Reserves.

VC: Vault Cash.
ER: Excess Reserves.

MP: Reserve Maintenance Period.

RCB: Required Clearing Balance.

RRR: Required Reserve Ratios. 
Footnotes:

1. Lag from the start of a computation period to the start of the corresponding maintenance period, unless noted otherwise.

2. This column indicates the numbers for tables in the appendix which provide details for reserve requirement systems of individual countries, and blanks in this column indicate no tables for the countries.

3. A MP begins on the settlement day of the first refinancing operation following the Governing Council meeting at which the monthly assessment of the monetary policy stance is scheduled, and ends on the day preceding the similar settlement day in the following month.

4. $\mathrm{Mr}_{\mathrm{i}}$ is the marginal interest rate (the lowest interest rate allotted at the auctions) for the most recent main refinancing operation settled on or before calendar day i, respectively, conducted by ECB and National Bank of Slovakia.

5. In Iceland and Switzerland, this is the lag from the end of a CP to the start of its corresponding MP.

6. Both the remuneration rate on RR and the penalty for shortfalls of averages required reserves are determined by the Board of Governors of the Central Bank of Iceland. Excess reserves are also remunerated at the current-account rate which is lower than the remuneration rate on $\mathrm{RR}$.

7. In Japan, RRRs vary by financial institution type, and by type and size of deposits and financial instruments. RRR on foreigncurrency liabilities held by residents is higher than those held by nonresidents.

8. Official discount rate is the rate applied to the discounting of bills by Bank of Japan.

9. In Korea, this is the percentage point of the penalty amount on the shortfalls of RR, not the rate of penalty interest on the shortfalls.

10. In Korea, RRRs vary by deposit type and currency denomination (domestic versus foreign currency) of deposits (lower RRR for foreign currency deposits).

11. The Bank of Mexico (BOM) uses a zero-average reserve requirement system (ZARR) to send monetary policy signals to financial markets without determining specific interest rate or exchange rate levels. Under ZARR, each commercial bank is required to maintain a zero average/accumulation of daily balances in its current account, subject to daily positive and negative limits, over each 28-calendar-day maintenance period (MP) in its current account with BOM.

12. The daily end-of-the-day overdrafts of current accounts exceeding the daily negative limit during a MP, or the end-of-theday negative accumulated balances at the end of a MP for the MP are charged interest at a rate equal to twice the 28-day CETES (Mexican's Treasury bill) rate. However, any positive balances during a MP or at the end of a MP are not remunerated. The positive or negative excess over the daily limits is excluded from the calculation of zero average/accumulated balance at the end of a MP, as it can not be used to offset the daily negative or positive balances during the MP.

13. Rediscount rate is the rate on money market bills issued by National Bank of Poland (NBP) through its open market operations.

14 Lombard rate is the landing rate on overnight loans from NBP to banks.

15. In Turkey, RRR is $6 \%$ for domestic-currency reservable liabilities and $11 \%$ for foreign-currency reservable liabilities. Required reserves on domestic-currency liabilities must be held in domestic currency, while those for foreign-currency liabilities must be held in euro or US dollars.

16. In Turkey, remuneration rate on Turkish-currency required reserves differs from those on foreign-currency required reserves. The former (13.25 as of September 20, 2006) is $75 \%$ of overnight lending rate of Turkish central bank, while the latter (2.540\% for U.S. dollar and 1.335\% for euro, as of 9/10/2006) are determined weekly, and equivalent to the rate on 2-day notice foreign exchange deposits that banks hold as free deposits with Turkish central bank.(See item 9 in table 12 for details).

17. In Turkey, holdings of interest-free deposits equal to $200 \%$ of the shortfall for liabilities denominated in Turkish-currency, but $300 \%$ of the deficiency for liabilities denominated in foreign-currencies.

18. In the U.K., participation in the reserve scheme is voluntary except for CHAPS sterling and CREST sterling settlement banks. Members of reserve scheme free to choose their individual reserve targets subject to some constraints, at least 2 business days before the start of each MP (see next footnote). Reserve targets can be changed from one MP to the next to any amounts limited by target ceilings.

19. Reserve targets are set in multiple of $£ 10$ million and bonded by zero and the ceilings. Ceilings are calculated twice a year, in May and November with new ceilings effective from the MPs starting in June and December. Ceilings are equal to the greater of $£ 1$ billion or $2 \%$ of the averages of the sterling eligible liabilities over the six months to April and October.

20. Actual average reserves up to the top of the target bands (equal to $+/-1 \%$ of the point targets declared) are remunerated at the MPC's official rate. Excess reserves above the top of the target bands are not remunerated.

21. Excess reserves above the tops of target bands or shortfalls of reserves below the bottoms of the bands are charged at the MPC's official rate and deducted from the interest paid. CHAPS or CREST settlement banks' overdrafts on individual days during the MP are charged twice the MPC's official rate and the charge is deducted from the account the next working day. Details for CHAPS and CREST are provided in footnotes 1 and 2 to table11 in the appendix. 
up in reserve accounts; and (3) costs associated with managing required reserves. To reduce the burden, many central banks have cut their required reserve ratios since the mid-1980s, remunerate interest on required reserve balances, and/or raised remuneration rates. ${ }^{20}$

To encourage interbank borrowing and lending, the remuneration in most countries is based on holdings of reserve balances up to the required amounts and is paid at a rate below overnight market rates. In other words, excess reserves are normally not remunerated, or are remunerated only on a limited portion or at a reduced rate. Consistent with the recent trends in reducing the burden of reserve requirements, most countries remunerate depository institutions for their holdings of required reserve balances. ${ }^{21}$ Two countries also remunerate for holdings of excess reserves, with one doing so at a rate below remuneration rate on required reserves (Iceland) and the other up to a limited amount (the United Kingdom).

Remuneration rates on required reserves can, in principle, vary or remain constant within a MP. Holding remuneration rates constant in a MP gives depository institutions an incentive to arbitrage expected movements in the overnight rate. As described above, this reduces volatility of the overnight rate within a MP. ${ }^{22}$ Hence, current remuneration rates in all OECD countries are constant in a MP - either set at a flat rate or at a rate equal to the average of specific daily official interest rates over a MP.

\section{Non-compliance penalty}

All OECD countries with a reserve requirement scheme impose penalties on failure to comply with reserve requirements. The majority assess penalties on the shortfalls of required reserves at a rate well above the country’s money market or lending rates. Some countries require depository institutions with deficient required reserves to hold interest-free deposits

${ }^{20}$ Since the mid-1980s, a number of central banks have eliminated their reserve requirements (see footnote 4).

${ }^{21}$ At present, the Federal Reserve System does not have statutory authority to remunerate depository institutions on required reserve balances and excess reserves. However, on October 13, 2006, the President of the United States signed The Financial Services Regulatory Relief Act of 2006, Pub. L. No. 109-351 (2006), which included the following provision (SEC. 201. Authorization for the Federal Reserve to Pay Interest on Reserves): "Balances maintained at a Federal Reserve bank by or on behalf of a depository institution may receive earnings to be paid by the Federal Reserve Bank at least once each quarter, at a rate or rates not to exceed the general level of short-term interest rates.” - with an effective date of October 1, 2011. This same legislation permits the Federal Reserve to reduce reserve requirements, or even eliminate them, with the same effective date.

${ }^{22}$ In contrast, varying remuneration rates in tandem with the overnight rate to ensure constant opportunity cost of holding reserve balances within a MP tends to reduce depository institution's incentive to arbitrage expected changes in the overnight rate. This has the effect of reducing fluctuations in daily reserve balances and boosting the undesirable volatility of the overnight rate in a MP. Varying remuneration rates in a MP would also complicate the remuneration process and increase the processing costs. 
at central banks, up to triple their deficiency for a time period at least as long as their MPs.

Korea levies a penalty payment at an amount equal to 1 percent of the shortfall. The United Kingdom imposes the same penalty on excess reserves above the top of target bands (equal

to $+/-1$ percent of the point targets declared by participants) as on the deficiency below the bottom of target bands, due to its zero surplus liquidity policy.

\section{Comparison of Reserve Requirement Systems}

There are similarities and differences among the main features of the thirteen reserve requirement systems in OECD countries. These reserve requirement systems can be roughly divided into three groups: one group consists of five highly heterogeneous reserve requirement systems - those in Japan, Korea, Switzerland, Turkey, and the United States; the second group comprises six very similar reserve systems - those in Czech Republic, the EMU, Hungary, Iceland, Poland, and Slovakia; and the third group includes two distinctive reserve requirement systems - those in Mexico and the United Kingdom.

Broad similarities and differences in the characteristics of the thirteen reserve requirement systems are first described. The similarities in the second group's systems are then discussed. Lastly, the unique features of the third group are pointed out.

\section{Comparison of the Thirteen Reserve Requirement Systems}

\subsection{Reservable liabilities}

There is variation in how OECD countries classify liabilities as reservable. All of them treat liabilities due to central banks as non-reservable. Twelve of them, except the United States, also exclude deposits due to other depository institutions, which are subject to the same reserve requirement system, from reservable liabilities. In the United States, transaction deposits due to other depository institutions after netting out those due from other depository institutions are subject to reserve requirements. Only the United States excludes personal non-transaction deposits from reservable liabilities. Two countries (Switzerland and the United Kingdom) classify foreign-currency denominated liabilities as non-reservable. Only the United Kingdom exempts some liabilities with long maturity from being reservable.

\subsection{Required reserve ratios}

Since mid-1980s, many central banks have reduced their required reserve ratios. The current marginal required reserve ratios for the OECD countries do not exceed 5 percent, 
except for the double-digit marginal required reserve ratios in Turkey and the United States. $^{23}$

Reserve requirement ratios (RRRs) can vary by one or more characteristics of the reservable liabilities (described in Section II.2). Japan varies its RRRs according to a wide variety of characteristics, such as deposit types and sizes, currency denomination, and residency of foreign-currency deposit holders. Japan also sets lower RRRs on deposits at Norinchukin Bank than those at other types of depository institutions. Seven countries vary RRRs with maturity and liability types. These are the EMU, Czech Republic, Hungary, Iceland, Poland, Slovakia, and Switzerland. The first six impose positive required reserve ratios only on reservable liabilities with a maturity up to two years. In Switzerland, only reservable liabilities maturing within three months are subject to a positive required reserve ratio. In addition to Japan, RRRs in the United States progress with deposit sizes. RRRs on foreign-currency liabilities in Turkey, besides Japan, differ from those on domestic-currency liabilities. ${ }^{24}$

1.3 Reserve computation periods and calculations of required reserves

Five countries - the EMU, Czech Republic, Hungary, Poland, and Slovakia - opt for the single month-end-date CP. Turkey's single-day CP is on every other Friday. In Iceland and Switzerland, required reserves are calculated based on averages of liabilities on the last day of two and three consecutive calendar months, respectively. In the remaining three countries - Japan, Korea, and the United States - required reserves are calculated based on averages of daily liabilities in a multi-day CP, ranging from fourteen days to one month.

\subsection{Types of reserve requirements}

Only Korea employs a semi-lagged reserve requirement system with a lag of one week from the start of each CP to the start of its associated MP. All other countries, except Mexico and the United Kingdom, have LRR (see Section III.3 for Mexico and the United Kingdom).

\subsection{Reserve maintenance periods and the CP to MP lag}

\footnotetext{
23 In the early 1990s, the Federal Reserve reduced the required reserve ratio for transaction deposits from 12 percent to 10 percent and that for nontransaction deposits from 3 percent to zero percent.

24 Turkey imposes a higher RRR on liabilities denominated in foreign currencies (11 percent) than those denominated in Turkish currency (6 percent).
} 
All central banks adopt multi-day MPs which range from fourteen days to five weeks. Most MPs start at least 3 weeks after the associated CPs. Compliance with reserve requirements is assessed based on averages of daily end-of-day reserve balances in a MP.

1.6 Eligible assets for satisfying required reserves

At present, only two central banks (Switzerland and the United States) accept VC up to 100 percent of required reserves, and one (Korea) up to 35 percent of required reserves with at least 65 percent of required reserves to be met with reserve balances. Nearly all central banks require depository institutions to hold reserve balances exclusively in domestic currencies. However, in Turkey, required reserves on foreign-currency denominated liabilities must be held in euro or US dollars, while those on domesticcurrency-denominated liabilities must be held in Turkish currency.

1.7 Carry-over and required clearing balances

Carry-over and RCB are employed only in the United States.

1.8 Remuneration on reserve balances

At present, five out of the thirteen countries do not pay interest on reserve balances Japan, Korea, Mexico, Switzerland, and the United States. ${ }^{25}$ The remaining countries remunerate on reserve balances up to the required amounts. Iceland also remunerates holdings of excess reserves but at a reduced rate. The United Kingdom remunerates holdings of excess reserves at the same rate as on targeted required reserves but only on the excess amount up to 1 percent of the targeted required reserve amounts declared by depository institutions.

Most remuneration rates are simple flat rates set at levels below overnight market interest rates. Remuneration rates in the EMU, Czech Republic, and Hungary are equal to the averages of the daily rates on short-term open market operations in a MP. In Turkey, required reserves denominated in foreign currencies are remunerated at a lower rate than those denominated in domestic currency.

1.9 Non-compliance penalty

All OECD countries with a reserve requirement system impose a penalty for failure to comply with reserve requirements. Most countries levy penalties on the deficiency of required reserves at interest rates equal to their overnight lending rates plus a margin. The

${ }^{25}$ See footnote 21 for details regarding the status for remunerating depository institutions in the United States. 
margin ranges from 1 to 5 percentage points or, for three countries, 100 percent of the lending rates or interest rate on short-term securities. Some countries will impose other forms of penalties. For example, some countries require depository institutions to hold interest-free deposits at an amount no less than the shortfall for a time period at least as long as a MP. Korea assesses a penalty payment at an amount equal to 1 percent of the shortfall. The United Kingdom assesses penalties on the amounts of shortfall below 99 percent or excess over 101 percent of the individual reserve targets at rates no less than its official rates.

\section{Similarities of the Six Reserve Requirement Systems in the Second Group}

The six reserve requirement systems in the second group (Czech Republic, the EMU, Hungary, Iceland, Poland, and Slovakia) are very similar and can be summarized below:

2.1 They employ LRR and have the same required-reserve-ratio structures. Their required reserves are all calculated using liabilities on a single-month-end date, except in Iceland where the average of liabilities on two month-end dates is used to calculate a depository institution's required reserve in a CP.

2.2 Their MPs span approximately one month with different starting and ending dates for each MP, resulting in slight variations in the lag between a CP and a MP. They all use reserveaveraging provisions for reserve maintenance and limit eligible assets for satisfying required reserves to reserve balances.

2.3 They remunerate based on averages of daily holdings of reserve balances only up to the required amounts, except Iceland which also remunerates on excess reserves at a reduced rate. The remuneration rates in the EMU, Czech Republic, and Hungary are calculated based on the averages of refinancing rates in open market operations. Iceland and Slovakia remunerate on required reserves at flat rates determined by their central banks. Poland's remuneration rate is equal to 90 percent of its discount rate.

2.4 The non-compliance penalties in five of these six countries, except Iceland, are either a high interest rate charged on the deficit of required reserves, or require holdings of a large amount of interest-free deposits.

\section{Unique Features of the Two Reserve Requirement Systems in the Third Group}

Countries in the third group (Mexico and the United Kingdom) have very distinctive reserve requirement schemes. Mexico has a zero average/accumulation reserve requirement 
system (ZARR). Under ZARR, each depository institution is required to maintain a zero average/accumulation of daily balances, subject to daily positive and negative limits, over each 28-day MP in its current account at the Bank of Mexico.

In the United Kingdom, participation in the reserve scheme is voluntary and participants are free to choose their reserve targets subject to target constraints. Participants have to specify their own non-negative reserve targets within their individual target ceilings at least two business days before the start of each MP. Target ceilings are calculated twice a year and are equal to the greater of $£ 1$ billion or two percent of the averages of the sterling-eligible liabilities over the six months before May and November.

These two reserve requirement systems have no CPs and required reserve ratios, as their required reserves are not calculated based on a depository institution's liabilities.

\section{Summary of Individual Reserve Requirement Systems}

This section describes the main features of each reserve requirement system in alphabetic order of the country's name.

\section{The reserve requirement system in Czech Republic}

1.1 Reservable liabilities: Czech Republic classifies reserve liabilities by maturity of liabilities in the same way as in the EMU. Reservable liabilities are the following:

a. Liabilities subject to a positive required reserve ratio

- Deposits: overnight deposits; deposits with agreed maturity up to 2 years; and deposits redeemable at notice up to 2 years.

-- Loans accepted from non-bank customers

-- Debt securities issued to non-banks except mortgage bonds with agreed maturity up to 2 years.

b. Liabilities subject to a zero required reserve ratio: Repo liabilities

c. Liabilities excluded from the reserve base

-- Liabilities vis-à-vis other institutions subject to minimum reserve system.

-- Liabilities vis-à-vis its central bank.

1.2 Required reserve ratio: The required reserve ratio is determined by its central bank and is at 2 percent.

1.3 Reserve computation period (CP): Required reserves are calculated based on liabilities on a single-month-end date of each calendar month. 
1.4 Reserve maintenance period (MP): MP spans about 1 month, and begins on the first Thursday of the second month following the computation date and ends on the Wednesday before the first Thursday of the following month. For example, for the computation date of July 31, 2006, the associated MP starts on September 7, 2006 and ends on October 4, 2006.

1.5 Types of reserve requirement: LRR is employed with a lag of about 1 month between its $\mathrm{CP}$ and the associated MP. Its reserve requirement system serves as a primary cushion for the smoothing functioning of the interbank payment system at the central bank's clearing system, rather than as a monetary policy instrument.

1.6 Calculation of required reserves: A depository institution's required reserve is 2 percent of its reserve base (sum of reservabe liabilities subject to positive required reserve ratio) on the CP date.

1.7 Eligible assets for satisfying required reserves: Only reserve balances held in reserve accounts with the central bank are eligible for meeting reserve requirements.

1.8 Remuneration on reserve balances: Interest is paid on the average of daily end-of-day reserve balances in a MP up to the minimum required amount, at a rate equal to the average of the central bank's two-week repo rates over the MP.

1.9 Non-compliance penalty: Penalty interest is assessed on the average deficient amount in a MP at a rate equal to twice the effective Lombard rate prevailing on each day of the MP.

\section{The reserve requirement system in the EMU}

The European Central Bank (ECB) is the central bank for the EMU. It issues euros and has been responsible for conducting monetary policy for the EMU since January 1, 1999.

2.1 Reservable liabilities: Reservable liabilities are classified by maturity, with liabilities maturing up to 2 years subject to a positive RRR and those maturing over 2 years subject to a zero RRR. Reservable liabilities are the following:

a. Liabilities with positive required reserve ratios

- Deposits: overnight deposits; deposits with agreed maturity up to 2 years; and deposits redeemable at notice up to 2 years.

-- Debt securities issued with agreed maturity up to 2 years.

-- Money market paper

b. Liabilities with a zero required reserve ratio 
- Deposits: deposits with agreed maturity over 2 years; and deposits redeemable at notice over 2 years.

-- Debt securities issued with agreed maturity over 2 years.

c. Liabilities excluded from the reserve base

-- Liabilities vis-à-vis other institutions subject to the ECB's reserve requirement system.

-- Liabilities vis-à-vis the ECB and the national central banks (NCBs).

2.2 Required reserve ratios: Required reserve ratios are determined by the ECB subject to the maximum limit specified in the Council Regulation concerning the application of minimum reserves by the ECB. A positive ratio is specified in the ECB Regulation on minimum reserves. Changes in reserve ratios are announced by the ECB in advance of the first MP for which the change is effective. The current positive required reserve ratio is 2 percent.

2.3 Reserve computation period (CP): Required reserves are calculated based on liabilities for a single-day CP on the month-end date for large institutions, which report full balance sheet data for each month-end. For small institutions, which report a limited set of balance sheet data for each quarter-end, their CP is the end-date of a calendar quarter.

2.4 Reserve maintenance period (MP): The MP begins on the settlement day of the main refinancing operation following the Governing Council meeting at which the monthly assessment of the monetary policy stance is scheduled. ${ }^{26}$ It ends on the day before the settlement day of the next main refinancing operation following the next Governing Council meeting. There are 12 Governing Council meetings in a year with each meeting spaced between 3 to 5 weeks, so the length of a MP varies from 3 to 5 weeks and on average is about 1 month. ${ }^{27}$ A MP starts about $1 \frac{1}{2}$ months for large institutions or $2 \frac{1}{2}$ months for small institutions after its associated reserve computation date. For example, for a computation date (reserve base data reported) of December 31, 2005, the MP for large institutions starts on February 8, 2006, but the first MP for small institutions begins on March 8, 2006 for three consecutive MPs.

2.5 Types of reserve requirement: LRR is employed with a $1 \frac{1}{2}$-month lag for large institution and $2 \frac{1}{2} 2$-month lag for small institutions. Its minimum reserve system serves two purposes:

${ }^{26}$ Until December 2003, the MPs start on the $24^{\text {th }}$ day of the month and ends on the $23^{\text {rd }}$ day of the following month. Schedules of GC meetings for 2006 and 2007 are listed in the two tables under footnote 2 to table 2 in the appendix.

27 Table 2 in the appendix (footnote 2) provides the calendars of GC meetings and MPs for 2006 and 2007. 
a. It helps to stabilize the overnight interest rate - banks have an incentive to lend liquidity (maintain ample reserves) when overnight interest rate is above (below) the remuneration rate of interest on required reserves.

b. It helps to ensure that the counterparties maintain a structural deficit vis-à-vis the Eurosystem, which is assumed to enhance the transmission of the monetary-policy target interest rates to the market interest rates. ${ }^{28}$

2.6 Calculation of required reserves: Required reserve amount is equal to 2 percent of each credit institution's reserve base (sum of all reservable liabilities subject to positive required reserve ratios) on the computation date minus EUR 100,000 (a lump-sum allowance for each credit institution).

2.7 Eligible assets for satisfying required reserves: VC is not allowed to meet required reserves. Eligible assets for fulfilling required reserves are limited to deposit balances in credit institutions' own or their intermediary's reserve accounts or settlement accounts with the ECB or their national central banks (NCBs).

2.8 Remuneration on reserve balances: The ECB and the NCBs in the EMU pay interests on the average of daily end-of-day reserve balances in a MP up to the required amounts (i.e. not on excess reserves). The remuneration rate is equal to the average, over a MP, of the ECB's rate (weighted according to the number of days) on the main refinancing operations, based on the formula below. The remuneration is paid on the second NCB business day following the end of the MP over which the remuneration was earned.

$$
\begin{aligned}
& \mathrm{R}_{\mathrm{t}}=\left(\mathrm{H}_{\mathrm{t}} \cdot \mathrm{n}_{\mathrm{t}} \cdot \mathrm{r}_{\mathrm{t}}\right) /(100.360) ; \mathrm{r}_{\mathrm{t}}=\left[\operatorname{Sum}\left(\mathrm{Mr}_{\mathrm{i}} /\left(\mathrm{n}_{\mathrm{t}}\right)\right] \text { for } \mathrm{i}=1, \ldots \mathrm{n}_{\mathrm{t}}\right. \text {. where: } \\
& \mathrm{R}_{\mathrm{t}}=\text { the remuneration to be paid on holdings of RR for MP t; } \\
& \mathrm{H}_{\mathrm{t}}=\text { average daily holdings of RR for MP } \mathrm{t} ; \\
& \mathrm{n}_{\mathrm{t}}=\text { the number of calendar days in a MP t; } \\
& \mathrm{r}_{\mathrm{t}}=\text { rate of remuneration on holdings of required reserves for the MP t (rounded to } 2 \\
& \quad \text { decimals). } \\
& \mathrm{i}=\text { the ith calendar day in MP } \mathrm{t} ;
\end{aligned}
$$

\footnotetext{
28 The Eurosystem comprises the ECB and the national central banks (NCBs) of those countries that have adopted the euro. The European System of Central Banks (ESCB) comprises the ECB and the NCBs of all European Community (EU) member states whether they have adopted the euro or not. The Eurosystem and the ESCB will coexist as long as there are EU member $r$ states outside the euro area.
} 
$\mathrm{Mr}_{\mathrm{i}}=$ the marginal interest rate (the lowest interest rate allotted at the auctions) for the most recent main refinancing operation settled on or before calendar day i.

2.9 Non-compliance penalty

Any one of the following sanctions may be imposed on an institution's shortfall of the average amount of daily minimum reserve balances in a MP:

a. An interest charge is assessed at a rate up to 5 percentage points above the marginal lending rate on the deficient amount;

b. An interest charge is assessed at a rate up to twice the marginal lending rate on the deficient amount;

c. The institution is required to hold interest-free deposits with the ECB or its NCB up to three times of the deficient amount with a maturity not exceeding the deficient period.

\section{The reserve requirement system in Hungary}

3.1 Reservable liabilities: Similar to the EMU and Czech Republic, reserve liabilities are classified by maturity of liabilities and are the following:

a. Liabilities with positive required reserve ratios (now 5 percent)

- Deposits: overnight deposits, deposits with remaining maturity up to 2 years at the time of entering into the balance sheet of the credit institutions, and deposits redeemable at notice up to 2 years at the time of entering into the balance sheet of the credit institutions.

-- Loans with remaining maturity over 2 years at the time of entering into the balance sheet of the credit institutions.

-- Debt securities issued with agreed maturity up to 2 years.

b. Liabilities with a zero required reserve ratio

- Deposits with remaining maturity over 2 years at the time of entering into the balance sheet of the credit institutions, and deposits redeemable at notice over 2 years at the time of entering into the balance sheet of the credit institutions.

-- Loans with remaining maturity over 2 years at the time of entering into the balance sheet of the credit institutions.

-- Debt securities issued with agreed maturity over 2 years.

-- Repos

c. Liabilities excluded from the reserve base 
-- Liabilities vis-à-vis other institutions subject to the Eurosystem’s minimum reserve system.

-- Outstanding total of loans from its central bank.

-- Liabilities arising from repurchase transactions with its central bank.

3.2 Required reserve ratios: The positive required reserve ratio has been 5 percent since August 1, 2002.

3.3 Reserve computation period: Like the EMU and Czech Republic, a depository institution's required reserves are based on liabilities on the last calendar day of each month.

3.4 Reserve maintenance period: A MP spans 1 month beginning on the $1^{\text {st }}$ calendar day of the $2^{\text {nd }}$ month following the computation date and ending on the last calendar day of that month.

3.5 Types of reserve requirement: LRR is employed with a lag of 1 month between the computation date and the associated MP.

3.6 Calculation of required reserves: Required reserves are calculated as 5 percent of the reserve base (sum of a depository institution's reservable liabilities subject to positive required reserve ratios on the computation date.

3.7 Eligible assets for satisfying required reserves: Only reserve balances can be used to satisfy required reserves, which are the deposit balances held by depository institutions or their intermediaries in the reserve accounts with their central bank.

3.8 Remuneration on reserve balances: Interest is paid on the averages of daily end-of-day required reserve balances in a MP up to the required minimum reserves, at a rate equal to the weighted average of the central bank's daily base rates in each MP (7.25 percent as of August 28, 2006). ${ }^{29}$ The interest is paid on the $2^{\text {nd }}$ business day of the month following the end of the MP.

3.9 Non-compliance penalty: For a depository institution's shortfall of the average of daily end-of-day reserve balances, the central bank debits the current account of the credit institution with the amount of the shortfall and holds it on a separate non-interest-bearing reserve account for 30 days. The credit institution is required to hold minimum reserves on the debit amount. If the shortfall is found during bank inspection of the credit institution

${ }^{29}$ MNB's base rate is the rate of interest on froint refinancing loans which is the credit extended by MNB to commercial banks for them to make loans to business organizations under specified programs. 
due to incorrect data supplied by the credit institution, its central bank may debit 1.5 times the amount of reserve deficiency for 30 days.

\section{The reserve required system in Iceland}

4.1 Reservable liabilities: Reservable liabilities are classified by maturity.

a. Liabilities with positive required reserve ratios

- Deposits: overnight deposits; deposits with agreed maturity up to 2 years; and deposits redeemable at notice up to 2 years.

-- Debt securities issued with agreed maturity up to 2 years.

-- Money market paper

b. Liabilities with a zero required reserve ratio

- Deposits: deposits with agreed maturity over 2 years; and deposits redeemable at notice over 2 years.

-- Debt securities issued with agreed maturity over 2 years.

-- Repos.

c. Liabilities excluded from the reserve base

-- Liabilities vis-à-vis the other credit institutions subject to the Iceland's reserve requirements.

-- Liabilities vis-à-vis the Iceland's central bank.

4.2 Required reserve ratios: The reserve ratios are determined by the Board of Governors of its central bank. The current positive required reserve ratio is set at 2 percent.

4.3 Reserve computation period: A CP consists of the last day of the preceding two calendar months before the beginning of each maintenance period.

4.4 Reserve maintenance period: Each MP spans 1 month, beginning on the $21^{\text {st }}$ day of the month following the end of the associated MP and ending on the $20^{\text {th }}$ day of the following month.

4.5 Types of reserve requirement: LRR is employed with a lag of 21 days from the end of each $\mathrm{CP}$ to the start of the corresponding MP. The reserve requirement system helps to stabilize the overnight interest rate - banks have incentive to lend liquidity (maintain ample reserves) when overnight interest rate is above (below) the rate of interest on required reserves.

4.6 Calculation of required reserves: Required reserves are 2 percent of the average of a depository institution's reserve base (sum of reservable liabilities subject to positive 
required reserve ratios) at the ends of the preceding two calendar months before the start of its MP.

4.7 Eligible assets for satisfying required reserves: Only reserve balances can be used to satisfy required reserves, which are the deposit balances held by credit institutions or their intermediaries in the current accounts with the central bank.

4.8 Remuneration on reserve balances: Interest is paid on the averages of daily end-of-day required reserve balances in a MP, and also on excess reserves. The interest rate on required reserves is decided by the Board of Governors of its central bank (12.75 percent as of September 22, 2006). Excess reserves are remunerated at the same rate of interest for the current accounts with the central bank held by institutions subject to minimum reserve requirements (12.50 percent as of September 22, 2006). ${ }^{30}$

4.9 Non-compliance penalty -- Periodic penalty payments levied on the shortfalls of the actual average required reserve balances versus the stipulated minimum reserve amounts are determined by the Board of Governors of the central bank by a special decision.

\section{The reserve requirement system in Japan}

5.1 Reservable liabilities: The following liabilities as reservable:

-- Deposits held with banks, long-term credit banks, Shinkin banks, and Norinchukin Bank

-- Debentures outstanding (yen-denominated bonds) issued by banks and long-term credit banks

-- Principal of Money Trusts (including loan trusts) outstanding

-- Foreign-currency denominated deposits

-- Liabilities in nonresidential yen accounts (excluding special international transaction accounts)

-- Balances transferred from special international transaction accounts to other accounts.

5.2 Required reserve ratios (RRRs): The structure of RRRs is more complex than those in other OECD countries. RRRs are lower for Norinchukin Bank than other depository institutions. In addition, RRRs vary with types and sizes of liabilities as well as the currency denominations of liabilities and residency of the holders of foreign currency deposits, as shown below:

${ }^{30}$ Overnight loan discount rate extended by CBI is $15 \%$ as of September 22, 2006. 
Reservable Liability

(excluding those vis-à-vis the Bank of Japan (BOJ) and other banks)

RRR

(\%)

-- Deposits held with banks, long-term credit banks, Shinkin banks, and Norinchukin Bank

(see below)

-- Debentures outstanding (yen-denominated bonds) issued by banks and long-term credit banks .................................................. 0.1

-- Principal of Money Trusts (including loan trusts) outstanding ...

-- Foreign-currency denominated deposits (see below)

-- Liabilities in nonresidential yen accounts (excluding special international transaction accounts)

-- Balances transferred from special international transaction accounts to other accounts

BOJ uses progressive reserve ratios where outstanding deposits are classified into brackets by value, and higher reserve ratios are applied to higher value brackets, except for Norinchukin Bank. Reserve ratios for outstanding deposits at the following amounts are:

Deposits denominated in yen

-- Over 2.5 trillion yen

-- 2.5 trillion yen or less, but over 1.2 trillion yen

-- 1.2 trillion yen or less, but over 0.5 trillion yen

-- 500 billion yen or less, but over 50 billion yen.
Time deposits Other deposits

0.9

0.05

0.05
(\%)

1.3

1.3

0.8

0.1

Nonresidents' foreign-currency denominated liabilities

(excluding special international transaction accounts).

$--$

0.15

Residents' foreign-currency denominated liabilities

(excluding special international transaction accounts)....

0.2

Deposits at Norinchukin Bank

0.05

0.1

5.3 Reserve computation period: A CP spans 1 month, beginning on the $1^{\text {st }}$ day of a calendar month and ending on the last day of the same month.

5.4 Reserve maintenance period: A MP spans 1 month, beginning on the $16^{\text {th }}$ day of the month after the $\mathrm{CP}$ and ending on the $15^{\text {th }}$ day of the following month.

5.5 Types of reserve requirement: LRR is employed with a lag of $1 \frac{1}{2}$ months from the start of a CP to the start of the corresponding MP 
5.6 Calculation of required reserves: A depository institution's required reserve is based on the average of daily balances of each type of an institution's reservable liabilities in the month of the CP. Total required reserve is calculated by multiplying the respective RRR for the each liability size and category by the associated amount, and then summing across the required balance for each liability size and category.

5.7 Eligible assets for satisfying reserve requirements: Only reserve balances can be used to satisfy reserve requirements, which are the deposit balances held by depository institutions or their intermediaries in the current accounts or special reserve accounts with the central bank.

5.8 Remuneration on reserve balances: Interest has never been paid on required reserves since the reserve requirement system was established in 1957.

5.9 Non-compliance penalty: An interest penalty is levied at a rate equal to the official discount rate plus an annual rate of 3.75 percentage points against the average of reserve deficiencies in a MP, and this penalty is paid to the government via the central bank.

\section{The reserve requirement system in Korea}

6.1 Reservable liabilities and required reserve ratios (RRRs): RRRs are set according to deposit types and the holder's residency of foreign currency deposits. Reservable liabilities and the associated RRRs are shown below:

-- Demand deposits, savings deposits, company savings deposits with a 5 percent RRR, but RRR is only 1 percent for non-resident's foreign currency deposits.

-- Time deposits, installment savings, mutual installments, housing installments, CDs sold to customers with a 2 percent RRR, but RRR is only 1 percent RRR for non-resident's foreign currency deposits.

-- Worker’s property formation savings, worker’s long-term savings, long-term savings deposits for housing, worker's savings for housing loans, long-term household savings deposits, worker’s preferential savings deposits with a 1 percent RRR.

6.2 Reserve computation period: A CP spans $1 / 2$ month. Each calendar month consists of two CPs with the $1^{\text {st }}$ one covering the $1^{\text {st }}$ half of the month $\left(1^{\text {st }}\right.$ to $\left.15^{\text {th }}\right)$ and the $2^{\text {nd }} \mathrm{CP}$ covering the $2^{\text {nd }}$ half of the month ( $16^{\text {th }}$ to the end of the month).

6.3 Reserve maintenance period: A MP spans $1 / 2$ month, and the MP associated with the $1^{\text {st }} \mathrm{CP}$ of each month starts on the $8^{\text {th }}$ of the month and ends on the $22^{\text {nd }}$ of that month; the MP 
associated with the $2^{\text {nd }} \mathrm{CP}$ of each month covers the $23^{\text {rd }}$ day of that month to the $7^{\text {th }}$ day of the following month.

6.4 Types of reserve requirements: A semi-lagged reserve requirement system is employed with a 7 -day lag from the start of a $1 / 2$-month CP to the start of the corresponding $1 / 2$-month MP.

6.5 Calculation of required reserves: A depository institution's required reserve is calculated by multiplying the average of daily balances in a CP for each of its reservable liability categories by the respective RRR, and then summing across required balances for each category.

6.6 Eligible assets for satisfying RR: Vault cash can be used to satisfy up to 35 percent of required reserves with the remaining (at least 65 percent) to be satisfied with balances of reserve deposits at the central bank.

6.7 Remuneration on reserve balances: Interest is not paid on balances of reserve deposits, although it was paid until 1986.

6.8 Non-compliance penalty: A penalty payment is assessed equal to 1 percent of the shortfall in term of average of reserves held in a MP. If the reserve deficiency lasts over 2-1/2 months, the Monetary Policy Committee can impose sanctions against the bank by banning the fresh extension of loans or the payment of dividends to shareholders until the bank has met its reserve requirement for more than 1 month.

\section{The zero-average reserve requirement system in Mexico}

7.1 A zero-average reserve requirement system (ZARR) is employed to send monetary policy signals to financial markets without determining specific interest rate or exchange rate levels.

7.2 Under ZARR, each commercial bank is required to maintain a zero average/accumulation of daily balances, subject to daily positive and negative limits, over each 28-calendar-day maintenance period (MP) in its current account with the central bank. ZARR is design to discourage banks from keeping positive balances or incurring overdrafts in their current accounts by lending or borrowing the funds to or from other banks at market interest rates.

7.3 Limits are imposed on daily positive and negative reserve balances that can be offset by other-day's negative and positive balances, to prevent banks from incurring excessive 
overdrafts. $^{31}$ The limits are determined on a case by case basis, according to the capital and liabilities of each credit institution. Any positive or negative excess over the daily limits is excluded from the calculation of zero average/accumulation of reserves over a MP, as it can not be offset by the daily negative or positive balances during the MP.

7.4 No interest is paid on any positive daily balances during maintenance periods or on positive accumulated balances at the end of a MP.

7.5 Interest is charged on daily overdrafts only on the amount over the limits and on the individual bank's negative accumulated balances at the end of a MP, at a rate equal to twice the 28-day CETES rate. ${ }^{32}$

7.6 To bring the total accumulated balances of all current accounts held by credit institutions in the central bank close to the pre-determined target (zero, positive or negative) amount, the central bank intervenes daily in the money market through auctions, by offering credit, deposits, repos, or carrying out direct purchases or sales of government securities.

\section{The reserve requirement system in Poland}

8.1 Reservable liabilities: Reservable liabilities are classified by maturity in the same way as the following four countries - the EMU, Czech Republic, Hungary, and Iceland.

Reservable liabilities are the following:

a. Liabilities with positive required reserve ratios (now 3.5 percent)

- Deposits: demand deposits; deposits with remaining maturity up to 2 years at the time of entering into the balance sheet of the credit institutions; and deposits redeemable at notice up to 2 years at the time of entering into the balance sheet of the credit institutions.

-- Loans with remaining maturity up to 2 years at the time of entering into the balance sheet of the credit institutions.

-- Debt securities issued with agreed maturity up to 2 years.

b. Liabilities with a zero required reserve ratio

${ }^{31}$ Excessive overdrafts could result in undue upward pressures on interest rates. To send signals on its monetary policy intentions, every day the central bank announces the target amount for the total accumulated balance (sum of the accumulated balances of all current accounts held by banks in the central bank) for the next business day. A zero total accumulated balance target would indicate the central bank's intention to meet, at the prevailing market interest rates, the full demand for liquidity. A negative (positive) total accumulated balance target would signal the central bank's intention to provide banks with insufficient (sufficient) liquidity at the prevailing market interest rates, resulting in upward (downward) pressures on interest rates.

${ }^{32}$ CETES (Certificates de la Tesoreria de la Federacion) are the Mexican counterparts of U.S. Treasury bills. 
- Deposits: deposits with remaining maturity over 2 years at the time of entering into the balance sheet of the credit institutions; and deposits redeemable at notice over 2 years at the time of entering into the balance sheet of the credit institutions.

-- Loans with remaining maturity over 2 years at the time of entering into the balance sheet of the credit institutions.

-- Debt securities issued with agreed maturity over 2 years.

-- Repos

c. Liabilities excluded from the reserve base

-- Liabilities vis-à-vis other institutions subject to Poland's minimum reserve requirement.

-- Outstanding total of loans from the central bank

-- Liabilities arising from repurchase transactions with the central bank.

8.2 Required reserve ratios: A positive required reserve ratio has been set at 3.5 percent since October 31, 2003.

8.3 Reserve computation period: A single-day CP on the last calendar day of each month is used.

8.4 Reserve maintenance period: A MP spans 1 calendar month, beginning on the $1^{\text {st }}$ calendar day and ending on the last calendar of the $2^{\text {nd }}$ month following the computation date.

8.5 Types of reserve requirement: LRR is employed with a one-month lag from the single-day CP to the start of the corresponding MP.

8.6 Calculation of required reserves: Similar to the formula used in the EMU, required reserve amount is equal to 3.5 percent of each credit institution's reserve base (sum of all reservable liabilities subject to positive required reserve ratios) on the computation date minus an amount in zloty (Polish’s currency) equivalent to 500,000 euro.

8.7 Eligible assets for satisfying required reserves: Only reserve balances in the accounts with the central bank can be applied toward required reserves.

8.8 Remuneration on reserve balances: Interests are paid on the averages of daily end-of-day required reserve balances in a MP up to the required minimum reserves, at a rate equal to 90 percent of rediscount rate on money market bills issued by the central bank through its open market operations.

8.9 Non-compliance penalty: When a bank fails to meet its reserve requirement, interest is assessed on the deficient amount at a rate (set by the Management Board of the central 
bank) no higher than twice the Lombard rate (landing rate on overnight loans from the central bank to banks).

\section{The reserve requirement system in Slovakia}

9.1 Reservable liabilities: Reservable liabilities are classified by maturity in the way as the following five countries - the EMU, Czech Republic, Hungary, Iceland, and Poland. Reservable liabilities are the liabilities:

a. Liabilities with a positive required reserve ratio

- Deposits: overnight deposits; deposits with agreed maturity up to 2 years; and deposits redeemable at notice up to 2 years.

-- Debt securities issued with agreed maturity up to 2 years.

-- Money market paper

b. Liabilities with a zero required reserve ratio

- Deposits: deposits with agreed maturity over 2 years; and deposits redeemable at notice over 2 years.

-- Debt securities issued with agreed maturity over 2 years.

-- Repos.

c. Liabilities excluded from the reserve base

-- Liabilities vis-à-vis other institutions subject to minimum reserve system.

-- Liabilities vis-à-vis Slovakia’s central bank.

9.2 Required reserve ratios: The current positive RRR is set at 2 percent.

9.3 Reserve computation period (CP): A CP is on the last calendar day of each month except December. $^{33}$

9.4 Reserve maintenance period: A MP spans 1 month, beginning on the first day and ending on the last calendar day of the second month following the computation date, except February MP. For example, for the computation date of November 30, 2005, the corresponding MP starts on January 1, 2006.

9.5 Types of reserve requirements: LRR is employed with a one-month lag from the singleday computation date to the start of the corresponding maintenance period (MP), except for the February MP.

\footnotetext{
33 The minimum required reserves to be maintained in February are computed based on the reservable liabilities as of November 30 of the previous year, instead of December 31 of that year.
} 
9.6 Calculation of required reserves: A depository institution's required reserve in a CP is 2 percent of the reserve base (sum of reservabe liabilities) on the computation date.

9.7 Eligible assets for satisfying required reserves: Only reserve balances held in reserve accounts with the central bank can be used to meet required reserves.

9.8 Remuneration on reserve balances: Interest is paid on the average of daily end-of-day reserve balances in a MP up to the minimum required amount at an annual rate of 1.5 percent, but not on excess reserves.

9.9 Non-compliance penalty: Similar to the EMU, penalty interest is assessed on the shortfalls of the average of daily end-of-day reserve balances in a MP at a rate equal to 5 percentage points above the overnight refinancing operations of its central bank prevailing on the last day of the MP for the number of calendar days in the MP.

\section{The reserve requirement system in Switzerland}

10.1 Reservable liabilities: Reservable liabilities are classified by maturity and are the following:

a. Liabilities subject to positive required reserve ratios (now 2.5 percent).

- Liabilities vis-à-vis banks payable on sight or maturing within 3 months if these banks are not themselves subject to Swiss minimum reserve requirements;

-- 20 percent of liabilities vis-à-vis customers in the form of savings and investments (excluding tied-up pension monies);

-- Other liabilities vis-à-vis customers payable on sight or maturing within 3 months;

-- Median-term bank-issued notes maturing within 3 months;

-- Money market paper maturing within 3 months.

b. Liabilities not subject to reserve requirements

-- Liabilities arising from repo transactions vis-à-vis Switzerland's central bank;

-- All liabilities vis-à-vis banks which are themselves subject to Switzerland's minimum reserve requirements;

-- Liabilities denominated in foreign currencies.

10.2 Required reserve ratios: The current positive RRR is 2.5 percent.

10.3 Reserve computation period: A CP consists of 3 days, which are the end-dates of three consecutive calendar months preceding the beginning of each maintenance period. 
10.4 Reserve maintenance period: A MP spans 1 month, beginning on the $20^{\text {th }}$ day of each calendar month following the end of the CP and ending on the $19^{\text {th }}$ day of the following month.

10.5 Types of reserve requirement: LRR system is employed with a 20-day lag from the end of a computation period to the start of the corresponding maintenance period.

10.6 Calculation of required reserves: A DI's required reserve is 2.5 percent of its reserve base (average of total reservable liabilities with a positive RRR on each of the three computation dates).

10.7 Eligible assets for satisfying reserve requirement: VC denominated in Swiss franc counted up to 100 percent of required reserves. Any remaining RR must be met by reserve balances. In other words, average of the sum of daily end-of-day balances in a MP of vault cash denominated in Swiss franc and balances in sight deposit accounts with the SNB must be no less than a DI's required reserve.

10.8 Remuneration on reserve balances: No interests are paid on reserve balances.

10.9 Non-compliance penalty: A penalty is the interest charged on the shortfall of the average of daily end-of-day reserve balances in a MP for a term of 30 days at a rate equal to three percentage points above one-month Libor for Swiss franc.

\section{The reserve requirement system in Turkey}

11.1 Reservable liabilities: Liabilities denominated in Turkish currency are treated separately from those denominated in foreign currencies (they differ in required reserve ratios and remuneration interest rates).

-- Reservable base is the sum of the total domestic liabilities after netting out the deductible items (see below), and the deposits/participation funds collected in Turkey on behalf of their branches abroad.

-- The following reservable liabilities are non-reservable:

a. Liabilities vis-à-vis the Central Bank of the Republic of Turkey (CBRT), Turkish Treasury Department, and other banks

b. Liabilities associated with equity capital, provisions, funds obtained from repo transactions, credits obtained from abroad with Treasury guaranty, and liabilities to the Head office and branches abroad (net) which are up to the amount of 
deposits/participation funds collected in Turkey on behalf of their branches abroad.

11.2 Required reserve ratios: The current RRR is 6 percent for Turkish currency liabilities and 11 percent for foreign exchange liabilities.

11.3 Reserve computation period: A CP consists of one single day (Friday in every two weeks). In other word, required reserves are calculated based on the balances of reservable liabilities on Friday which is also the first day of the MP associated with the previous CP.

11.4 Reserve maintenance period: A MP spans 14 days, and each MP begins on Friday in every two weeks, which is also the Friday of the next $C P$, and ends on the $2^{\text {nd }}$ Thursday of the MP.

11.5 Types of reserve requirement: A lagged reserve requirement (LRR) is used, with a 14day lag from the computation date to the start of the corresponding 14-day maintenance period.

11.6 Calculation of required reserves: Required reserves are calculated, respectively, for liabilities denominated in Turkish currency and those denominated in foreign currencies, by multiplying the applicable RRR to the reserve base on each computation date.

11.7 Eligible assets for satisfying required reserves: A bank must hold its required reserves, in New Turkish Lira for the Turkish liabilities and in U.S. dollar and/or euro for foreign exchange liabilities, in its accounts with the Turkish central bank. An institution's averages of the daily end-of-day balances in its accounts in a MP must satisfy its required reserves for all Turkish liabilities. Required reserves for the 3percent portion of the 11 percent RRR for foreign exchange liabilities are maintained according to the averaging provision. However, required reserves for the remaining 8percent portion of the 11-percent RRR are maintained in blocked accounts. Therefore, quasi-averaging provision is applied in the maintenance of required reserves for foreign exchange liabilities.

11.8 Remuneration on reserve balances: Interest is on the average balance of a MP of Turkish required reserves at a rate (13.12 percent as of 9/10/2006) equal to 75 percent of overnight lending rate charged by the central bank. The remuneration rate on 
foreign exchange required reserves (2.540 percent for U.S. dollar and 1.335 percent for euro, as of September 10, 2006) are determined weekly, and equivalent to the rate on 2-day notice foreign-currency deposits that banks hold as free deposits with Turkish central bank. (It is almost half of market interest rates such as LIBOR or FIBOR). The remunerations are accrued at the end of each calendar quarter.

11.9 Non-compliance penalty: If a bank fails to comply with reserve requirements on time or with insufficient amounts, it is required to hold interest-free deposits in blocked accounts with the central bank in the amount double the deficient portion of Turkish currency required reserves in term of New Turkish Lira, three-fold the deficient portion of the foreign exchange required reserves in term of U.S. dollar, taking into account the periods of deficiency. Otherwise, the bank is assessed with interest payments on the average deficient amount in the MP at a rate equal to 150 percent of the maximum overnight lending rate announced by the central bank on the last day of the MP.

\section{Reserve account facility in the United Kingdom}

12.1 Reserve account type: Participation in the reserve scheme is voluntary except for CHAPS sterling and CREST sterling settlement banks. ${ }^{34}$ Participants specify their individual non-negative reserve targets constrained by target ceilings at least 2 business days before the start of each maintenance period. ${ }^{35}$

12.2 Eligible reservable liabilities: Reservable liabilities are used to calculate target ceilings. They must be denominated in sterling but excluding all deposits and repurchase agreements with the central bank. They are the following:

-- Deposits with original maturity up to 2 years - sight deposits, time deposits and CDs.

-- Cash loaded smart cards

-- Commercial paper and issues of other paper with original maturity up to 5 years

-- Liabilities under sale and repurchase agreements

-- Items in suspense including all credit balances relating to customers' funds, but not in customers' names and awaiting transfer or investment, etc.

-- Credit items in the course of transmission.

\footnotetext{
${ }^{34}$ See footnotes 1 and 2 to table 11.

35 The aggregated reserve targets for all participants are published on the working day before the start of the MP by BOE.
} 
12.3 Reserve target specification: Participants are free to choose their reserve targets which are set in multiples of $£ 10$ million and bonded by zero and the target ceilings (see item 12.5 below). Reserve targets must be set at least 2 business days before the start of each MP and can be changed from one MP to the next with no constraints on the size of changes except the limitation of target ceilings.

12.4 Reserve maintenance period: A MP spans 1 month. Each MP normally starts on the policy decision day of the Monetary Policy Committee (MPC) and ends on the day before the next month’s MPC policy announcement (normally a Thursday and a Wednesday respectively). Thus, some MPs are four weeks and some five weeks.

12.5 Calculation of reserve target ceiling: Ceilings are calculated twice a year, in May and November with new ceilings effective from the MPs starting in June and December. Ceilings are equal to the greater of $£ 1$ billion or 2 percent of the averages of the sterling eligible liabilities over the six months to April and October.

12.6 Eligible assets for reserve account: Participants must hold their reserves in their reserve or settlement accounts at the central bank. Reserve balances can be varied freely to meet day-to-day liquidity needs, but the average of daily end-of-day reserve balances in each MP must not be outside the target band (equal to $+/-1$ percent of the point target declared) to avoid penalty.

12.7 Remuneration on reserve balances: Interest is paid on the average reserve balance in a MP up to the target band at the central bank's official rate. Any excess reserve above the top of the target band is not remunerated. If average reserves are lower than the target band, the actual average balance is remunerated at the official rate. Interest is paid on the basis of 365 days a year and paid up to the last day of the MP. Interest is credited directly to the participant's reserve account on the first day of the following MP.

12.8 Penalty: Any excess reserve above the top of target band or shortfall of reserve below the bottom of the band are charged at the official rate and deducted from the interest paid. CHAPS or CREST settlement banks' overdrafts on individual days during a MP are charged twice the official rate and the charge is deducted from the account the next working day. ${ }^{36}$

${ }^{36}$ For details of CHAPS and CREST, see footnotes 1 and 2 to table 11 in the appendix. 


\section{The reserve requirement system in the United States}

13.1 Reservable liabilities: RRRs are based on types and sizes of deposits at depository institutions. Currently only deposits in net transaction accounts are subject to positive required RRRs (see footnote 1 to table 12 in the appendix for definition of net transactions). RRRs vary with the average amount of a depository institution's daily net transaction deposits in a MP. Non-personal time and savings deposits, and net Eurocurrency liabilities are currently subject to zero RRR.

13.2 Required reserve ratios (RRRs): Progressive RRRs are applied to the averages of net transaction deposits (NT) in the MP.

$0 \%$ for NT up to reserve exemption level (\$8.5 million for 2007);

$3 \%$ for NT above reserve exempt level up to low reserve tranche level (\$45.8 million for 2007);

$10 \%$ for NT above low reserve tranche level. ${ }^{37}$

13.3 Reserve computation period (CP): Each CP spans 14 days for weekly deposit reporters, beginning every other Tuesday and ending on the second Monday. The CP for quarterly deposit reporters consists of 7 days, beginning on the third Tuesday of March, June, September, and December and ending on the following Monday.

13.4 Reserve maintenance period (MP): For weekly reporters, each MP comprises 14 days with a lag of 30 days from the associated CP, beginning on the fifth Thursday after the start of the associated CP and ending on the second Wednesday. For quarterly reporters, the MP comprises 7 days. The required reserves for each CP have to be maintained for 12-14 consecutive MPs, called "a reserve maintenance cycle”, until the first MP associated with the $\mathrm{CP}$ in the next quarter begins. Thus, the first MP begins also with a lag of 30 days from the associated CP, beginning on the fifth Thursday after the start of the associated CP and ending on the following Wednesday.

13.5 Types of reserve requirements: LRR is employed, with a lag of 30 days from the start of a reserve computation period to the start of the associated maintenance period.

13.6 Calculation of required reserves: Required reserves are equal to the sum of the products of each of the three RRRs times the corresponding tier of the average of a depository

\footnotetext{
${ }^{37}$ Both the exemption amount and low reserve tranche level for each year are adjusted by an indexation method based on the most recent June 30-to-June 30 growth of total reservable liabilities and total net transaction balances of the depository institutions.
} 
institution's daily net transaction deposit balances in a CP. For example, a depository institution with an average of daily net transaction deposits of \$100 million in a CP has required reserves equal to $\$ 6.539$ million as calculated below:

$$
\begin{aligned}
& \text { Required reserves }=(\$ 8.5 \text { million } \times 0.0)+[(\$ 45.8 \text { million }-\$ 8.5 \text { million }) \times 0.03] \\
& +[(\$ 100.0 \text { million }-\$ 45.8 \text { million }) \times 0.10] .
\end{aligned}
$$

13.7 Eligible assets for satisfying RR: A depository institution can apply its VC to meet up to 100 percent of its required reserves. A depository institution's remaining required reserves after applying its VC, called its reserve balance requirement, must be satisfied by its reserve balance at the central bank.

13.8 Carry-over of reserve balances: A depository institution with a reserve balance requirement is allowed to carry over some excess reserve or deficiency of required reserve balances in one MP to be used or made up only in the following MP. The allowable carry-over of reserve balances is limited to the greater of $\$ 50,000$ or 4 percent of the total requirement (reserve requirement plus required clearing balance, if any), less clearing balance allowance, if applicable.

13.9 Remuneration on reserve balances: Reserve balances are not remunerated by the FRBs. $^{38}$

13.10 Non-compliance penalty: A charge on the average deficiency of daily reserve balances in a MP is assessed at a rate equal to 1 percentage point (annual rate) above the primary credit rate in effect for borrowing from the central bank on the first day of the month in which the deficiency occurs. In other words, the penalty on reserve deficiency is 2 percentage points above the target overnight rate, as the primary credit rate is currently 1 percentage point over the target fed funds rate.

13.11 Required clearing balance (RCB): A RCB is an amount that a depository institution may contract to maintain at its FRB in addition to its reserve balance requirement. The amount of a RCB must be set before the start of the effective MP; it can be adjusted prior to each MP. The average of a depository institution's daily end-of-day RCBs in a MP needs to fall within its clearing balance band which is its RCB plus or minus the

38 See footnote 21 for details regarding the status of the Federal Reserve's authority for remunerating depository institutions in the United States. 
greater of $\$ 25,000$ or 2 percent of the RCB. The average of actual RCB in a MP, up to the top of the band, earns interest credit which is calculated based on the prevailing earnings credit rate and two adjustments. ${ }^{39}$ Earnings credit may be used to offset charges of eligible FRB services incurred in the subsequent 52 weeks. Unused excess earnings credit is forfeited. Earnings credit is not transferable.

39 A representation of the formula for calculating earning credits is:

$$
e=b *\left[\left(1-M R R_{R B}\right) * \text { erate }+M R R_{1} * \text { ffrate }\right]
$$

where $e$ is total earnings credits, $b$ is the average end-of-day clearing balance maintained (after application of any asof adjustments) during the maintenance period, $M R R_{R B}$ is the Reserve Bank's imputed marginal reserve requirement ratio (10 percent), erate is the earning credit rate (the rolling 13-week average of the annualized coupon equivalent yield of three-month Treasury bill rate in the secondary market), $M R R_{t}$ is the institution's marginal reserve requirement ratio $(0,3 \%$, or $10 \%)$, and ffrate is the average effective federal funds rate over the maintenance period. Prior to January 2004, the earnings credit rate was equal to the effective federal funds rate. 


\section{APPENDIX}

\section{Table 1}

Main Features of the Minimum Reserve Requirement System in Czech Republic ${ }^{1}$

\begin{tabular}{|c|c|}
\hline Feature & Description \\
\hline 1. RR Type & Lagged RR (LRR) \\
\hline $\begin{array}{l}\text { 2. Reservable Liabilities and } \\
\text { Required Reserve Ratios } \\
\text { (RRR) }\end{array}$ & $\begin{array}{l}\text { Reservable Liability denominated in Czech koruna (CZK) and foreign currencies } \\
\text { (excluding those vis-à-vis the Czech National Bank (CNB), and other depository } \\
\text { institutions): } \\
\text { Liabilities with positive RRR (currently 2\%) } \\
\text {-- Deposits: overnight deposits; time deposits with agreed maturity up to } 2 \text { years; savings } \\
\quad \text { deposits redeemable at notice up to } 2 \text { years } \\
\text {-- Loans accepted from non-bank customers } \\
\text {-- Debt securities issued to non-banks except mortgage bonds with agreed maturity up to } \\
2 \text { years. } \\
\text { Liabilities with zero RRR } \\
\text {-- Repo liabilities }\end{array}$ \\
\hline $\begin{array}{l}\text { 3. Reserve Computation } \\
\text { Period (CP) }\end{array}$ & 1 day, each CP is on the last day of each calendar month. \\
\hline $\begin{array}{l}\text { 4. Reserve Maintenance } \\
\text { Period (MP) }\end{array}$ & $\begin{array}{l}\text { 4-5 weeks, a MP begins on the } 1^{\text {st }} \text { Thursday of the } 2^{\text {nd }} \text { month after the computation date, } \\
\text { and ends on Wednesday before the } 1^{\text {st }} \text { Thursday of the following month, e.g. the MP that } \\
\text { starts on September } 7,2006 \text { ends on October } 4,2006 \text {. }\end{array}$ \\
\hline 5. Lag (from CP to start of MP) & $4-5$ weeks from the CP to the start of the corresponding MP. \\
\hline $\begin{array}{l}\text { 6. Calculation of Required } \\
\text { Reserves (RR) }\end{array}$ & $\begin{array}{l}\text { RR is calculated as } 2 \% \text { of each institution's reserve base (sum of reservable liabilities } \\
\text { subject to a positive RRR) on the computation date. }\end{array}$ \\
\hline $\begin{array}{l}\text { 7. Eligible Assets for Meeting } \\
\text { Reserve Requirement } \\
\text { - Vault Cash (VC) - No } \\
\text { - Reserve Balance (RB) -- } \\
\text { Yes }\end{array}$ & $\begin{array}{l}\text { Vault Cash (VC) - not eligible for satisfying RR } \\
\text { Reserve Balance (RB) - a bank must hold its required minimum reserves in CZK in its } \\
\text { reserve account or "payment system account" or other account with the CNB, with the } \\
\text { average of the daily end-of-day balances in the account in a MP not less than its required } \\
\text { minimum reserves. }\end{array}$ \\
\hline $\begin{array}{l}\text { 8. Carry-Over } \\
\text { - RB -- No }\end{array}$ & $\begin{array}{l}\text { A DI is not allowed to carry over any excess reserves or deficiency of its minimum } \\
\text { reserves in one MP to be used or made up in the following MP. }\end{array}$ \\
\hline 9. Remuneration --Yes & $\begin{array}{l}\text { The average of actual reserve balances in a MP up to the required amount held with the } \\
\text { CNB are remunerated at the average rate for CNB's limit two-week repos taken over the } \\
\text { MP. The remuneration is paid on the second business day following the end of the MP } \\
\text { over which the remuneration was earned. Excess reserves are not remunerated. } \\
\qquad \mathrm{R}_{\mathrm{t}}=\left(\mathrm{H}_{\mathrm{t}} \cdot \mathrm{n}_{\mathrm{t}} \cdot \mathrm{r}_{\mathrm{t}}\right) /(100.360) ; \mathrm{r}_{\mathrm{t}}=\text { [Sum }\left(\mathrm{RPr}_{\mathrm{i}} /\left(\mathrm{n}_{\mathrm{t}}\right)\right] \text { for } \mathrm{i}=1, \ldots \mathrm{n}_{\mathrm{t}} \text {. where: } \\
\mathrm{R}_{\mathrm{t}}=\text { the remuneration to be paid on holdings of } \mathrm{RR} \text { for MPt; } \\
\mathrm{H}_{\mathrm{t}}=\text { average daily holdings of RR for MP t; } \\
\mathrm{n}_{\mathrm{t}}=\text { the number of calendar days in the MP t; } \\
\mathrm{r}_{\mathrm{t}} \quad=\text { rate of remuneration; } \\
\mathrm{i} \quad=\text { the ith calendar day in MP t; } \\
\mathrm{RPr}_{\mathrm{i}}=\text { the limit interest rate for two-week repos on day i. }\end{array}$ \\
\hline 10. Penalty -- Yes & $\begin{array}{l}\text { CNB charges penalty interest on the deficient average of daily balances in a MP at a rate } \\
\text { double the effective Lombard rate prevailing during each day of the MP. }\end{array}$ \\
\hline $\begin{array}{l}\text { 11. Required Clearing } \\
\text { Balance (RCB) -- No }\end{array}$ & RCB does not exist in this country. \\
\hline
\end{tabular}

1. The institutions subject to reserve requirements are: banks, building society and branch offices of foreign banks that have a banking license in the Czech Republic or intend to operate in Czech Republic. 
Table 2

Main Features of the Minimum Reserve Requirements in the EMU

\begin{tabular}{|c|c|}
\hline Feature & Description \\
\hline 1. RR Type & Lagged RR (LRR) \\
\hline $\begin{array}{l}\text { 2. Reservable Liabilities and } \\
\text { Required Reserve Ratios } \\
\text { (RRR) }\end{array}$ & $\begin{array}{l}\text { Reservable Liability (excluding those vis-à-vis the ECB, the National Central Banks } \\
\text { (NCBs), and other institutions subject to the ECB's minimum reserve system) } \\
\text { Liabilities with positive RRR (currently } 2 \%)^{1} \\
\text {--Deposits: Overnight deposits; deposits with agreed maturity up to } 2 \text { years, and } \\
\text { deposits redeemable at notice up to } 2 \text { years } \\
\text {--Debt securities issued with agreed maturity up to } 2 \text { years } \\
\text {--Money market paper } \\
\text { Liabilities with zero RRR } \\
\text {--Deposits: Deposits with agreed maturity over } 2 \text { years, and } \\
\quad \text { deposits redeemable at notice over } 2 \text { years } \\
\text {--Debt securities issued with agreed maturity over } 2 \text { years } \\
\text {-- Repos }\end{array}$ \\
\hline $\begin{array}{l}\text { 3. Reserve Computation } \\
\text { Period (CP) }\end{array}$ & $\begin{array}{l}\text { - For large institutions (which report full balance sheet data for each month-end) } \\
\text { - a CP is the end-date of a calendar month. } \\
\text { - For small institutions (which report a limited set of balance sheet data for each quarter- } \\
\text { end) - a CP is the end-date of a calendar quarter. }\end{array}$ \\
\hline $\begin{array}{l}\text { 4. Reserve Maintenance } \\
\text { Period (MP) } \\
\text { - Start - settlement day of } \\
\text { the main refinancing opera- } \\
\text { tion following the GC } \\
\text { meeting. }\end{array}$ & $\begin{array}{l}\text { - For large institutions - It varies from } 3 \text { to } 5 \text { weeks, about } 1 \text { month on average. A MP } \\
\text { begins on the settlement day of the first main refinancing operation following the } \\
\text { Governing Council (GC) meeting at which the monthly assessment of the monetary } \\
\text { policy stance is scheduled. It normally ends on the day preceding the similar settlement } \\
\text { day in the following month. }{ }^{2} \\
\text { - For small institutions - Each MP starts and ends on the same dates as that for large } \\
\text { institutions; but for reserve base data reported on each quarter-end date, the required } \\
\text { minimum reserves are held for } 3 \text { consecutive MPs with the } 1^{\text {st }} \text { MP begins about } 2-1 / 2 \\
\text { months after the data reporting date. }{ }^{2}\end{array}$ \\
\hline 5. Lag (from CP to start of MP) & About $1 \frac{1 / 2}{2}$ months for large institutions, or $2 \frac{1}{2}$ months for small institutions ${ }^{2}$ \\
\hline $\begin{array}{l}\text { 6. Calculation of Required } \\
\text { Reserves (RR) } \\
\text { - } \text { Reserve Base - data on } \\
\text { month- or quarter-end date } \\
\text { - } \mathbf{R R R}-2 \% \text { or } 0 \%\end{array}$ & $\begin{array}{l}\text { RR is calculated as } 2 \% \text { of an institution's reserve base (sum of all reservable liabilities } \\
\text { subject to a positive RRR) on the computation date, minus a lump-sum allowance (now } \\
\text { EUR 100,000). For example, a DI with a reserve base of EUR100 million on January 31, } \\
\text { its RR is EUR1.9 million as calculated below: } \\
\text { Required reserves = (EUR100 million x 0.02) - EUR100,000 (lump-sum allowance). }\end{array}$ \\
\hline $\begin{array}{l}\text { 7. Eligible Assets for Meeting } \\
\text { Reserve Requirement } \\
\text { - Vault Cash (VC) - No } \\
\text { - Reserve Balance (RB) -- } \\
\text { Yes }\end{array}$ & $\begin{array}{l}\text { Vault Cash (VC) - not eligible for satisfying RR } \\
\text { Reserve Balance (RB) - an institution must hold its minimum reserves in its reserve } \\
\text { account(s) (or settlement accounts) or indirectly through an intermediary with the ECB or } \\
\text { NCB in the Member State in which it is established, with the average of the daily end-of- } \\
\text { day balances in its reserve accounts in a MP not less than its required minimum reserves. }\end{array}$ \\
\hline 8. Remuneration --Yes & 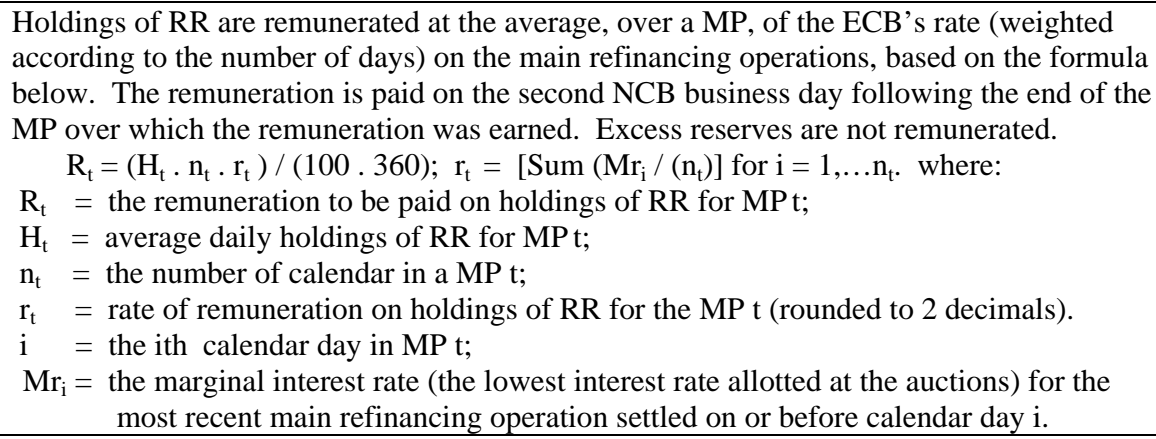 \\
\hline 9. Penalty -- Yes & $\begin{array}{l}\text { ECB may impose any one of the following sanctions on an institution's deficient average } \\
\text { amount of its daily minimum reserve balances in a MP: } \\
\text {--Accessing a payment on the deficiency at a rate up to } 5 \% \text { above the } \mathrm{Mr}_{\mathrm{i}} \text {. } \\
\text {--Accessing a payment on the deficiency at a rate up to double the } \mathrm{Mr}_{\mathrm{i}} \text {. } \\
\text {--Requiring the institution to hold interest-free deposits with the ECB or its NCB up to } \\
\text { three times of the deficiency with a maturity not exceeding the deficient period. }\end{array}$ \\
\hline
\end{tabular}


1. The reserve ratios are determined by the ECB subject to the maximum limit specified in the Council Regulation (EC) concerning the application of minimum reserves by the ECB. The positive ratio is specified in the ECB Regulation on minimum reserves. Changes in reserve ratios are announced by the ECB in advance of the first MP for which the change is effective.

2. The published 12 MPs for 2006 and 2007, respectively, are shown in the following two tables. The length of the MP varies somewhat, but on average it is about one month. Each MP starts about 1-1/2 month for large institutions and 2-1/2 month for small institutions after its reserve base reporting (or computation) date. For example, for reserve base data reported on December 31, 2005 (reserve computation date), the MP for large institutions started on February 8, 2006, and ended on March 7, 2006. However, the first MP of the three consecutive MPs for small institutions began on March 8, 2006 and ended on April 11, 2006, with the third MP starting on May 10, 2006 and ending on June 14, 2006.

Note: A main refinancing operation is regular open market operation executed by the ECB in the form of a reverse transaction (an operation whereby the national central bank buys or sells assets under a repurchase agreement or conducts credit operations against collateral.) Main refinancing operations are conducted through weekly standard tenders and normally have a maturity of one week.

\section{Indicative calendar of reserve maintenance periods for 2006}

\begin{tabular}{|c|c|c|c|c|c|c|}
\hline MP & $\begin{array}{c}\text { Relevant } \\
\begin{array}{c}\text { Governing Council } \\
\text { meeting }\end{array}\end{array}$ & $\begin{array}{c}\text { Start of } \\
\text { maintenance } \\
\text { period }\end{array}$ & $\begin{array}{c}\text { End of maintenance } \\
\text { period }\end{array}$ & $\begin{array}{l}\text { Reserve base data for } \\
\text { credit institutions } \\
\text { reporting monthly }\end{array}$ & $\begin{array}{l}\text { Reserve base data for } \\
\text { credit institutions } \\
\text { reporting quarterly }\end{array}$ & $\begin{array}{l}\text { Length of the } \\
\text { maintenance } \\
\text { period (days) }\end{array}$ \\
\hline 1 & 12 January 2006 & 18 January 2006 & 7 February 2006 & November 2005 & September 2005 & 21 \\
\hline 2 & 2 February 2006 & 8 February 2006 & 7 March 2006 & December 2005 & September 2005 & 28 \\
\hline 3 & 2 March 2006 & 8 March 2006 & 11 April 2006 & January 2006 & December 2005 & 35 \\
\hline 4 & 6 April 2006 & 12 April 2006 & 9 May 2006 & February 2006 & December 2005 & 28 \\
\hline 5 & 4 May 2006 & 10 May 2006 & 14 June 2006 & March 2006 & December 2005 & 36 \\
\hline 6 & 8 June 2006 & 15 June 2006 & 11 July 2006 & April 2006 & March 2006 & 27 \\
\hline 7 & 6 July 2006 & 12 July 2006 & 8 August 2006 & May 2006 & March 2006 & 28 \\
\hline 8 & 3 August 2006 & 9 August 2006 & 5 Sept. 2006 & June 2006 & March 2006 & 28 \\
\hline 9 & 31 August 2006 & 6 Sept.. 2006 & 10 October 2006 & July 2006 & June 2006 & 35 \\
\hline 10 & 5 October 2006 & 11 October 2006 & 7 November 2006 & August 2006 & June 2006 & 28 \\
\hline 11 & 2 November 2006 & 8 November 2006 & 12 December 2006 & September 2006 & June 2006 & 35 \\
\hline 12 & 7 December 2006 & 13 Dec. 2006 & 16 January 2007 & October 2006 & September 2006 & 35 \\
\hline
\end{tabular}

Indicative calendar of maintenance periods for 2007

\begin{tabular}{|c|c|c|c|c|c|c|}
\hline MP & $\begin{array}{c}\text { Relevant } \\
\text { Governing } \\
\text { Council meeting }\end{array}$ & $\begin{array}{c}\text { Start of } \\
\text { maintenance } \\
\text { period }\end{array}$ & $\begin{array}{c}\text { End of } \\
\text { maintenance } \\
\text { period }\end{array}$ & $\begin{array}{l}\text { Reserve base data for } \\
\text { credit institutions } \\
\text { reporting monthly }\end{array}$ & $\begin{array}{l}\text { Reserve base data for } \\
\text { credit institutions } \\
\text { reporting quarterly }\end{array}$ & \begin{tabular}{|c|}
$\begin{array}{c}\text { Length of } \\
\text { maintenance period } \\
\text { (days) }\end{array}$ \\
\end{tabular} \\
\hline 1 & 11 January 2007 & 17 January 2007 & 13 February 2007 & November 2006 & September 2006 & 28 \\
\hline 2 & 8 February 2007 & 14 February2007 & 13 March 2007 & December 2006 & September 2006 & 28 \\
\hline 3 & 8 March 2007 & 14 March 2007 & 17 April 2007 & January 2007 & December 2006 & 35 \\
\hline 4 & 12 April 2007 & 18 April 2007 & 14 May 2007 & February 2007 & December 2006 & 27 \\
\hline 5 & 10 May 2007 & 15 May 2007 & 12 June 2007 & March 2007 & December 2006 & 29 \\
\hline 6 & 6 June 2007 & 13 June 2007 & 10 July 2007 & April 2007 & March 2007 & 28 \\
\hline 7 & 5 July 2007 & 11 July 2007 & 7 August 2007 & May 2007 & March 2007 & 28 \\
\hline 8 & 2 August 2007 & 8 August 2007 & 11 Sept. 2007 & June 2007 & March 2007 & 35 \\
\hline 9 & 6 Sept. 2007 & 12 Sept. 2007 & 9 October 2007 & July 2007 & June 2007 & 28 \\
\hline 10 & 4 October 2007 & 10 October 2007 & 13 November 2007 & August 2007 & June 2007 & 35 \\
\hline 11 & 8 Nov. 2007 & 14 Nov. 2007 & 11 December 2007 & September 2007 & June 2007 & 28 \\
\hline 12 & 6 Dec. 2007 & 12 Dec. 2007 & 15 January 2008 & October 2007 & September 2007 & 35 \\
\hline
\end{tabular}


Table 3

Main Features of the Minimum Reserve Requirement System in Hungary ${ }^{1}$

\begin{tabular}{|c|c|}
\hline Feature & Description \\
\hline 1. RR Type & Lagged RR (LRR) \\
\hline \multirow{2}{*}{$\begin{array}{l}\text { 2. Reservable Liabilities and } \\
\text { Required Reserve Ratios } \\
\text { (RRR) }\end{array}$} & $\begin{array}{l}\text { Reservable Liability (excluding those with the Magyar Nemzeti Bank (MNB), and other } \\
\text { institutions subject to the MNB’s minimum reserve system) }\end{array}$ \\
\hline & $\begin{array}{l}\text { Liabilities with positive RRR (currently } 5 \%)^{1} \\
\text {-- Deposits: overnight deposits, deposits with remaining maturity up to } 2 \text { years at the time } \\
\text { of entering into the balance sheet of the credit institutions, and deposits redeemable at } \\
\text { notice up to } 2 \text { years at the time of entering into the balance sheet of the credit } \\
\text { institutions. } \\
\text {-- Loans with remaining maturity up to } 2 \text { years at the time of entering into the balance } \\
\text { sheet of the credit institutions. } \\
\text {-- Debt securities issued with agreed maturity up to } 2 \text { years } \\
\text { Liabilities with zero RRR } \\
\text {--Deposits with remaining maturity over } 2 \text { years at the time of entering into the balance } \\
\text { sheet of the credit institutions, and deposits redeemable at notice over } 2 \text { years at the } \\
\text { time of entering into the balance sheet of the credit institutions; } \\
\text {--Debt securities issued with agreed maturity over } 2 \text { years } \\
\text {-- Repos }\end{array}$ \\
\hline $\begin{array}{l}\text { 3. Reserve Computation } \\
\text { Period (CP) }\end{array}$ & 1 day, the last calendar of each month. \\
\hline $\begin{array}{l}\text { 4. Reserve Maintenance } \\
\text { Period (MP) }\end{array}$ & $\begin{array}{l}1 \text { month, a MP begins on the } 1^{\text {st }} \text { calendar day of the } 2^{\text {nd }} \text { month after the computation date } \\
\text { and ends on the last calendar day of that month. }\end{array}$ \\
\hline 5. Lag & 1 month for from the computation date to the start of the corresponding MP. \\
\hline $\begin{array}{l}\text { 6. Calculation of Required } \\
\text { Reserves (RR) }\end{array}$ & $\begin{array}{l}\text { RR is calculated as 5\% of the reserve base (total reservable liabilities subject to a positive } \\
\text { RRR) of an institution, excluding data for branches abroad, on the computation date. }\end{array}$ \\
\hline $\begin{array}{l}\text { 7. Eligible Assets for Meeting } \\
\text { Reserve Requirement } \\
\text { - Vault Cash (VC) - No } \\
\text { - Reserve Balance (RB) -- } \\
\text { Yes }\end{array}$ & $\begin{array}{l}\text { Vault Cash (VC) - not eligible for satisfying RR } \\
\text { Reserve Balance (RB) - an institution must hold its minimum reserves in its reserve } \\
\text { account(s) (or payment system accounts) or indirectly through an intermediary with the } \\
\text { MNB. } \\
\quad \text { An institution's average of the daily end-of-day balances in its reserve accounts in a } \\
\text { MP must satisfy its RR. }\end{array}$ \\
\hline $\begin{array}{l}\text { 8. Carry-Over } \\
\text { - RB -- No }\end{array}$ & $\begin{array}{l}\text { A DI is not allowed to carry over any excess reserves or deficiency of its minimum } \\
\text { reserves in one MP to be used or made up in the following MP. }\end{array}$ \\
\hline 9. Remuneration --Yes & $\begin{array}{l}\text { Holdings of RR are remunerated on the average of daily balances in a MP up to the } \\
\text { required minimum reserves based on the formula below. The remuneration is paid on the } \\
\text { second NCB business day following the end of the MP over which the remuneration was } \\
\text { earned. Excess reserves are not remunerated. } \\
\quad \mathrm{R}_{\mathrm{t}}=\left(\mathrm{H}_{\mathrm{t}} \cdot \mathrm{n}_{\mathrm{t}} \cdot \mathrm{r}_{\mathrm{t}}\right) /(100.360) ; \mathrm{r}_{\mathrm{t}}=\left[\text { Sum }\left(\mathrm{j}_{\mathrm{i}} /\left(\mathrm{n}_{\mathrm{t}}\right)\right] \text { for } \mathrm{i}=1, \ldots \mathrm{n}_{\mathrm{t}} \text {. where: }\right. \\
\mathrm{R}_{\mathrm{t}}=\text { the remuneration to be paid on holdings of RR for MP } \mathrm{t} \text {; } \\
\mathrm{H}_{\mathrm{t}}=\text { average daily holdings of RR for MP } \mathrm{t} \text {; } \\
\mathrm{n}_{\mathrm{t}}=\text { the number of calendar in a MP t; } \\
\mathrm{r}_{\mathrm{t}}=\text { interest rate remunerated on holdings of RR for the MP t (rounded to } 2 \text { decimals). } \\
\mathrm{i} \quad=\text { the ith calendar day in MP t; } \\
\mathrm{j}_{\mathrm{i}}=\text { the interest rate remunerated on the ith calendar day of MP t. }{ }^{2}\end{array}$ \\
\hline 10. Penalty -- Yes & $\begin{array}{l}\text { For a credit institution's shortfall in term of the average of daily minimum reserves in each } \\
\text { MP, the MNB debits the current account of the credit institution at the amount of the } \\
\text { shortfall and holds it on a separate non-interest-bearing reserve account for } 30 \text { days. The } \\
\text { credit institution is required to hold minimum reserves on the debit amount. If the shortfall } \\
\text { is due to the credit institution's misreported data and uncovered during authority's } \\
\text { inspection, the MNB debits } 1.5 \text { times the amount of reserve deficiency and hold it in a } \\
\text { separate interest-free reserve account for } 30 \text { days. The credit institution is also required to } \\
\text { hold minimum reserves on the debit amount. }\end{array}$ \\
\hline
\end{tabular}

1. Credit institutions having operating license including Hungarian branches of foreign credit institutions are required to hold reserves.

2. The daily remunerated interest rate is equal to MNB's base rate -- the rate of interest on froint refinancing loans which is the credit extended by MNB to commercial banks for them to make loans to business organizations under specified programs. 
Table 4

Main Features of Minimum Reserve Requirements in Iceland ${ }^{1}$

\begin{tabular}{|c|c|}
\hline Feature & Description \\
\hline 1. RR Type & Lagged RR (LRR) \\
\hline \multirow{2}{*}{$\begin{array}{l}\text { 2. Reservable Liabilities and } \\
\text { Required Reserve Ratios } \\
\text { (RRR) }\end{array}$} & $\begin{array}{l}\text { Reservable Liability (excluding those vis-à-vis the Central Bank of Iceland (CBI) and } \\
\text { other credit institutions ) }\end{array}$ \\
\hline & $\begin{array}{l}\text { Liabilities with positive RRR (currently } 2 \%)^{1} \\
\text {--Deposits: overnight deposits; deposits with agreed maturity up to } 2 \text { years; } \\
\quad \text { deposits redeemable at notice up to } 2 \text { years } \\
\text {--Debt securities issued with agreed maturity up to } 2 \text { years } \\
\text {--Money market paper } \\
\text { Liabilities with zero RRR } \\
\text {--Deposits: deposits with agreed maturity over } 2 \text { years; } \\
\quad \text { deposits redeemable at notice over } 2 \text { years; repos } \\
\text {--Debt securities issued with agreed maturity over } 2 \text { years } \\
\text {--Repos }\end{array}$ \\
\hline $\begin{array}{l}\text { 3. Reserve Computation } \\
\text { Period (CP) }\end{array}$ & $\begin{array}{l}\text { Last day of two subsequent calendar months, reserve base is the average of the reservable } \\
\text { liabilities at the end of the preceding two calendar months before the corresponding } \\
\text { maintenance period. }\end{array}$ \\
\hline $\begin{array}{l}\text { 4. Reserve Maintenance } \\
\text { Period (MP) }{ }^{5}\end{array}$ & $\begin{array}{l}1 \text { month, each MP starts on the } 21^{\text {st }} \text { day of each calendar month and ends on the } 20^{\text {th }} \text { day of } \\
\text { the following month. }\end{array}$ \\
\hline 5. Lag & A 21-day lag from the end of a CP to the start of the corresponding MP. \\
\hline $\begin{array}{l}\text { 6. Calculation of Required } \\
\text { Reserves (RR) }\end{array}$ & $\begin{array}{l}\text { RR is calculated as } 2 \% \text { of the average balance of the total reserve liabilities with a positive } \\
\text { RRR of an institution on the computation dates. }\end{array}$ \\
\hline $\begin{array}{l}\text { 7. Eligible Assets for Meeting } \\
\text { Reserve Requirement } \\
\text { - Vault Cash (VC) - No } \\
\text { - Reserve Balance (RB) -- } \\
\text { Yes }\end{array}$ & $\begin{array}{l}\text { Vault Cash (VC) - not eligible for satisfying RR } \\
\text { Reserve Balance (RB) - an institution must hold its minimum reserves in its current } \\
\text { account (for reserves and settlement purposes) or indirectly through an intermediary with } \\
\text { the CBI. } \\
\text { An institution's average of the daily end-of-day balances in its current account in a MP } \\
\text { must satisfy its RR. }\end{array}$ \\
\hline $\begin{array}{l}\text { 8. Carry-Over } \\
\text { - RB -- No }\end{array}$ & $\begin{array}{l}\text { A DI is not allowed to carry over any excess reserves or deficiency of its minimum } \\
\text { reserves in one MP to be used or made up in the following MP. }\end{array}$ \\
\hline 9. Remuneration --Yes & $\begin{array}{l}\text { Holdings of RR are remunerated based on the average balance of a MP at a rate of interest } \\
\text { on required reserves determined by the Board of Governors of the CBI ( } 12.75 \% \text { as of } \\
\text { September 22, 2006). An average balance in excess of the minimum reserve amount is } \\
\text { remunerated at the same rate of interest (also set by the Board of Governors of the CBI) for } \\
\text { current accounts with the CBI held by institutions subject to minimum reserve } \\
\text { requirements }(12.50 \% \text { as of September } 22,2006) \text {. }\end{array}$ \\
\hline 10. Penalty -- Yes & $\begin{array}{l}\text { Periodic penalty payments levied on the shortfalls of the actual average required reserve } \\
\text { balances versus the stipulated minimum reserve amounts are determined by the Board of } \\
\text { Governors of the CBI by a special decision. }\end{array}$ \\
\hline $\begin{array}{l}\text { 11. Required Clearing } \\
\text { Balance (RCB) -- No }\end{array}$ & \\
\hline
\end{tabular}

1. Institutions subject to minimum reserve requirements: commercial banks, savings banks and credit cooperatives. 
Table 5

Main Features of the Reserve Requirement System in Japan ${ }^{1}$

\begin{tabular}{|c|c|c|}
\hline Feature & \multicolumn{2}{|l|}{ Description } \\
\hline 1. RR Type & \multicolumn{2}{|l|}{ Lagged RR (LRR) } \\
\hline \multirow{2}{*}{$\begin{array}{l}\text { 2. Reservable Liabilities and } \\
\text { Required Reserve Ratios } \\
\text { (RRR) }\end{array}$} & $\begin{array}{l}\text { Reservable Liability (excluding those vis-à-vis the Bank of Japan (BOJ) and } \\
\text { other banks ) }\end{array}$ & $\begin{array}{l}\text { RRR } \\
(\%)\end{array}$ \\
\hline & 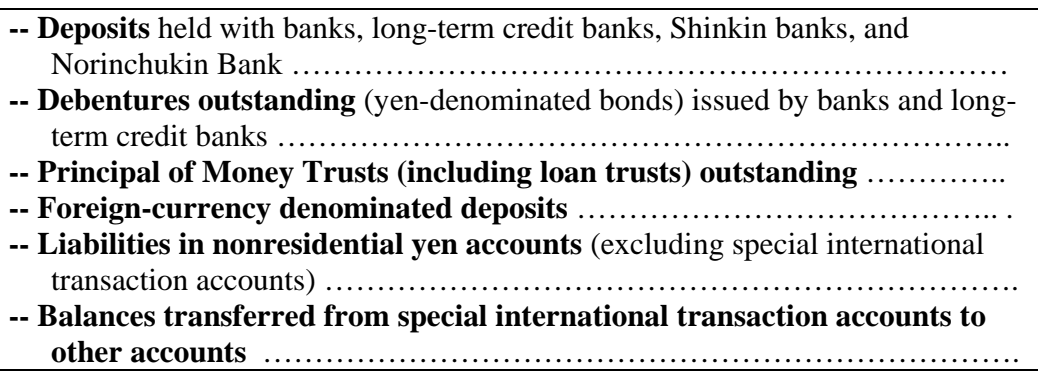 & $\begin{array}{c}0.1 \\
0.1 \\
\operatorname{vary}^{2} \\
0.15 \\
0.15\end{array}$ \\
\hline $\begin{array}{l}\text { 3. Reserve Computation } \\
\text { Period (CP) }\end{array}$ & \multicolumn{2}{|l|}{1 month, each CP starts on the first day and ends on the last day of each month. } \\
\hline $\begin{array}{l}\text { 4. Reserve Maintenance } \\
\text { Period (MP) } \\
\end{array}$ & \multicolumn{2}{|l|}{$\begin{array}{l}1 \text { month, each MP starts on the } 16^{\text {th }} \text { of a calendar month and ends on the } 15^{\text {th }} \text { day of the } \\
\text { following month. }\end{array}$} \\
\hline 5. Lag & \multicolumn{2}{|l|}{ A lag of $1 \frac{112}{2}$ months from the start of a CP to the start of the corresponding MP. } \\
\hline $\begin{array}{l}\text { 6. Calculation of Required } \\
\text { Reserves (RR) }\end{array}$ & \multicolumn{2}{|l|}{$\begin{array}{l}\text { RR is calculated by multiplying the average of daily balances in a CP for each type of an } \\
\text { institution's reservable liabilities by the respective RRR, and then summing up the results. }\end{array}$} \\
\hline $\begin{array}{l}\text { 7. Eligible Assets for Meeting } \\
\text { Reserve Requirement } \\
\text { - Vault Cash (VC) - No } \\
\text { - Reserve Balance (RB) -- } \\
\text { Yes }\end{array}$ & \multicolumn{2}{|l|}{$\begin{array}{l}\text { Vault Cash (VC) - not eligible for satisfying RR } \\
\text { Reserve Balance (RB) - an institution must hold its required reserves in its current } \\
\text { account (for reserves and settlement purposes) or special reserve account with the BOJ or } \\
\text { indirectly through an intermediary. } \\
\text { An institution's average of the daily end-of-day balances in its current account in a MP } \\
\text { must satisfy its RR. }\end{array}$} \\
\hline $\begin{array}{l}\text { 9. Carry-Over } \\
\text { - RB -- No }\end{array}$ & \multicolumn{2}{|l|}{$\begin{array}{l}\text { A DI is not allowed to carry over any excess reserves or deficiency of its minimum } \\
\text { reserves in one MP to be used or made up in the following MP. }\end{array}$} \\
\hline 9. Remuneration -- No & \multicolumn{2}{|l|}{ BOJ has never paid interest on required reserves. } \\
\hline 10. Penalty -- Yes & \multicolumn{2}{|l|}{$\begin{array}{l}\text { A penalty equal to the official discount rate plus an annual rate of } 3.75 \text { percentage points is } \\
\text { levied against reserve deficiencies, and this penalty is paid to the government via the BOJ. }\end{array}$} \\
\hline $\begin{array}{l}\text { 11. Required Clearing } \\
\text { Balance (RCB) -- No }\end{array}$ & \multicolumn{2}{|l|}{ 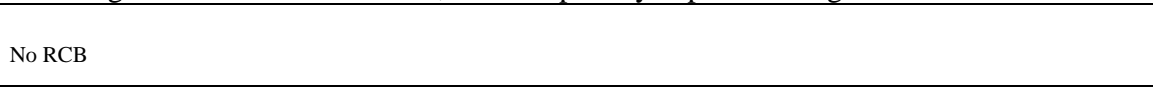 } \\
\hline
\end{tabular}

1. Financial institutions subject to reserve requirements include city banks, regional banks, regional banks II, trust banks, branches of foreign banks in Japan, long-term credit banks, shinkin banks (those with deposits over 160 billion yen at fiscal yearend), and Norinchukin Bank.

2. BOJ uses progressive reserve ratios where outstanding deposits are classified into brackets by value, and higher reserve ratios are applied to higher value brackets, except for Norinchukin Bank. Reserve ratios for outstanding deposits at the following amounts are:

Deposits denominated in yen

-- Over 2.5 trillion yen

-- 2.5 trillion yen or less, but over 1.2 trillion yen

-- 1.2 trillion yen or less, but over 0.5 trillion yen

-- 500 billion yen or less, but over 50 billion yen.

Nonresidents' foreign-currency denominated liabilities

(excluding special international transaction accounts)......

Residents’ foreign-currency denominated liabilities

(excluding special international transaction accounts).......

Deposits at Norinchukin Bank

\begin{tabular}{|c|c|}
\hline Time deposits & Other deposits \\
\hline (\%) & (\%) \\
\hline 1.2 & 1.3 \\
\hline 0.9 & 1.3 \\
\hline 0.05 & 0.8 \\
\hline 0.05 & 0.1 \\
\hline
\end{tabular}

$-$

0.15

0.2

0.25

0.05

0.1 
Table 6

Main Features of the Reserve Requirement System in Korea ${ }^{1}$

\begin{tabular}{|c|c|c|}
\hline Feature & \multicolumn{2}{|l|}{ Description } \\
\hline 1. RR Type & \multicolumn{2}{|l|}{ Semi-lagged RR } \\
\hline \multirow{2}{*}{$\begin{array}{l}\text { 2. Reservable Liabilities and } \\
\text { Required Reserve Ratios } \\
\text { (RRR) }\end{array}$} & $\begin{array}{l}\text { Reservable Liability (excluding those vis-à-vis the Bank of Korea (BOK) and } \\
\text { other banks ) }\end{array}$ & $\begin{array}{c}\mathbf{R R R}^{2} \\
(\%)\end{array}$ \\
\hline & $\begin{array}{l}\text {-- Demand deposits, savings deposits, company savings deposits ............. } \\
\text {-- Time deposits, installment savings, mutual installments, housing } \\
\text { installments, CDs sold to customers .................................... } \\
\text {-- Worker's property formation savings, worker’s long-term savings, long-term } \\
\text { savings deposits for housing, worker's savings for housing loans, long-term } \\
\text { household savings deposits, worker's preferential savings deposits } \ldots \ldots \ldots .\end{array}$ & $2.0^{2}$ \\
\hline $\begin{array}{l}\text { 3. Reserve Computation } \\
\text { Period (CP) }\end{array}$ & \multicolumn{2}{|c|}{$\begin{array}{l}1 / 2 \text { month, each calendar month consists of two CPs with the } 1^{\text {st }} \text { one covering the } 1^{\text {st }} \text { half of } \\
\text { the month }\left(1^{\text {st }} \text { to } 15^{\text {th }} \text { day of the month), and the } 2^{\text {nd }} C P \text { covering the } 2^{\text {nd }} \text { half of the month }\right. \\
\left(16^{\text {th }} \text { to the end of the month). }\right.\end{array}$} \\
\hline $\begin{array}{l}\text { 4. Reserve Maintenance } \\
\text { Period (MP) }\end{array}$ & \multicolumn{2}{|c|}{$\begin{array}{l}1 / 2 \text { month, the MP corresponding to the } 1^{\text {st }} \mathrm{CP} \text { of each month starts on the } 8^{\text {th }} \text { of the month } \\
\text { and ends on the } 22^{\text {nd }} \text { of that month; the MP corresponding to the } 2^{\text {nd }} \mathrm{CP} \text { of each month } \\
\text { covers the } 23^{\text {rd }} \text { day of that month to the } 7^{\text {th }} \text { day of the following month. }\end{array}$} \\
\hline 5. Lag & \multicolumn{2}{|l|}{1 week lag from the start of a CP to the start of the corresponding MP. } \\
\hline $\begin{array}{l}\text { 6. Calculation of Required } \\
\text { Reserves (RR) } \\
\end{array}$ & \multicolumn{2}{|c|}{$\begin{array}{l}\text { RR is calculated by multiplying the average of daily balances in a CP for each of an } \\
\text { institution's reservable liabilities by the respective RRR, and then summing up the results. }\end{array}$} \\
\hline $\begin{array}{l}\text { 7. Eligible Assets for Meeting } \\
\text { Reserve Requirement } \\
\text { - Vault Cash (VC) - Yes } \\
\text { - Reserve Balance (RB) -- } \\
\text { Yes }\end{array}$ & \multicolumn{2}{|c|}{$\begin{array}{l}\text { Vault Cash (VC) - up to 35\% of RR may be satisfied by VC. } \\
\text { Reserve Balance (RB) - an institution must deposit at least } 65 \% \text { of its required reserves in } \\
\text { its account (for reserves and settlement purposes) with the BOK or indirectly through an } \\
\text { intermediary. } \\
\text { An institution's average of the daily sum of its eligible VC and the end-of-day balances } \\
\text { of reserve deposits in a MP must satisfy its RR. }\end{array}$} \\
\hline $\begin{array}{l}\text { 8. Carry-Over } \\
\text { - RB -- No }\end{array}$ & \multicolumn{2}{|c|}{$\begin{array}{l}\text { A DI is not allowed to carry over any excess reserves or deficiency of its minimum } \\
\text { reserves in one MP to be used or made up in the following MP. }\end{array}$} \\
\hline 9. Remuneration -- No & \multicolumn{2}{|c|}{ The BOK does not pay interest on reserve deposits, although it did until 1986.} \\
\hline 10. Penalty -- Yes & \multicolumn{2}{|c|}{$\begin{array}{l}\text { A penalty equal to } 1 \% \text { of the shortfall in term of average of reserves held in a MP is levied } \\
\text { by the BOK. If the reserve deficiency lasts over } 2-1 / 2 \text { months, the Monetary Policy } \\
\text { Committee can impose sanctions against the bank by banning the fresh extension of loans } \\
\text { or the payment of dividends to shareholders until the bank has met its RR for more than } 1 \\
\text { month. }\end{array}$} \\
\hline $\begin{array}{l}\text { 11. Required Clearing } \\
\text { Balance (RCB) -- No }\end{array}$ & & \\
\hline
\end{tabular}

1. Financial institutions subject to reserve requirements consist of commercial banks, special banks and the Korea Development Bank (KDB). Non-bank financial institutions also should hold a certain ratio of liquid assets as reserve in compliance with their respective regulations. However, this is to prepare against ordinary withdraws by depositors, and is not related to monetary policy. In addition, these reserves are mostly held in the form of profit yielding assets.

2. RRR for non-resident's foreign currency deposits is only $1 \%$. 
Table 7

Main Features of the Minimum Reserve Requirement System in Poland

\begin{tabular}{|c|c|}
\hline Feature & Description \\
\hline 1. RR Type & Lagged RR (LRR) \\
\hline $\begin{array}{l}\text { 2. Reservable Liabilities and } \\
\text { Required Reserve Ratios } \\
\text { (RRR) }\end{array}$ & $\begin{array}{l}\text { Reservable Liability regardless of currency denominations (excluding those with the } \\
\text { National Bank of Poland (NBP), and other institutions subject to the NBP's minimum } \\
\text { reserve system): } \\
\text { Liabilities with positive RRR (currently 3.5\%) } \\
\text {-- Deposits: demand deposits; deposits with remaining maturity up to } 2 \text { years at the time of } \\
\text { entering into the balance sheet of the credit institutions; deposits redeemable at notice } \\
\text { up to } 2 \text { years at the time of entering into the balance sheet of the credit institutions } \\
\text {-- Loans with remaining maturity up to } 2 \text { years at the time of entering into the balance } \\
\text { sheet of the credit institutions } \\
\text {-- Debt securities issued with agreed maturity up to } 2 \text { years } \\
\text { Liabilities with zero RRR } \\
\text {--Deposits: deposits with remaining maturity over } 2 \text { years at the time of entering into the } \\
\text { balance sheet of the credit institutions; deposits redeemable at notice over } 2 \text { years at the } \\
\text { time of entering into the balance sheet of the credit institutions; } \\
\text {--Debt securities issued with agreed maturity over } 2 \text { years } \\
\text {-- Repos }\end{array}$ \\
\hline $\begin{array}{l}\text { 3. Reserve Computation } \\
\text { Period (CP) }\end{array}$ & 1 day, the last calendar day of each month. \\
\hline $\begin{array}{l}\text { 4. Reserve Maintenance } \\
\text { Period (MP) }\end{array}$ & $\begin{array}{l}1 \text { month, a MP begins on the } 1^{\text {st }} \text { calendar day and ends on the last calendar day of the } 2^{\text {nd }} \\
\text { month after the computation date. }\end{array}$ \\
\hline 5. Lag & 1 month for from the computation date to the start of the corresponding MP. \\
\hline $\begin{array}{l}\text { 6. Calculation of Required } \\
\text { Reserves (RR) }\end{array}$ & $\begin{array}{l}\text { RR is first calculated as 3.5\% (RRR) of an institution's reserve base (total reservable } \\
\text { liabilities subject to a positive RRR) on the computation date, and then the result is reduced } \\
\text { by an amount in the zloty (domestic currency) equivalent to 500,000 euro. }\end{array}$ \\
\hline $\begin{array}{l}\text { 7. Eligible Assets for Meeting } \\
\text { Reserve Requirement } \\
\text { - Vault Cash (VC) - No } \\
\text { - Reserve Balance (RB) -- } \\
\text { Yes } \\
\end{array}$ & $\begin{array}{l}\text { Vault Cash (VC) - not eligible for satisfying RR } \\
\text { Reserve Balance (RB) - an institution must hold its minimum reserves in the zloty in its } \\
\text { reserve account(s) or payment system accounts or indirectly through an intermediary with } \\
\text { the NBP, with the average of its daily end-of-day balances in a MP no less than its RR. }\end{array}$ \\
\hline $\begin{array}{l}\text { 8. Carry-Over } \\
\text { - RB -- No }\end{array}$ & $\begin{array}{l}\text { A DI is not allowed to carry over any excess reserves or deficiency of its minimum } \\
\text { reserves in one MP to be used or made up in the following MP. }\end{array}$ \\
\hline 9. Remuneration --Yes & $\begin{array}{l}\text { Holdings of RR are remunerated at the remuneration rate on the average of daily balances } \\
\text { in a MP up to the required minimum reserves at a rate equal to } 90 \% \text { of rediscount rate on } \\
\text { NBP's money market bills. }{ }^{1} \text { Excess reserves are not remunerated. }\end{array}$ \\
\hline 10. Penalty - Yes & $\begin{array}{l}\text { When a bank fails to meet its minimum reserve requirement, the NBP assesses interest on } \\
\text { the deficient amount at a rate set by the resolution of the NBP's Management Board which } \\
\text { is no higher than twice the Lombard rate. }\end{array}$ \\
\hline $\begin{array}{l}\text { 11. Required Clearing } \\
\text { Balance (RCB) -- No }\end{array}$ & \\
\hline
\end{tabular}

1. Bill rediscount rate is the interest rate on the money market bills issued by NBP through open market operations, which is very close to the main NBP interest rate (reference rate).

2. The Lombard rate is the lending rate on overnight loans to banks from NBP, which determines the ceiling for fluctuations of the overnight rates in interbank market. 
Table 8

\section{Main Features of the Minimum Reserve Requirement System in Slovakia ${ }^{1}$}

\begin{tabular}{|c|c|}
\hline Feature & Description \\
\hline 1. RR Type & Lagged RR (LRR) \\
\hline $\begin{array}{l}\text { 2. Reservable Liabilities and } \\
\text { Required Reserve Ratios } \\
\text { (RRR) }\end{array}$ & $\begin{array}{l}\text { Reservable Liability (excluding those vis-à-vis the National Bank of Slovakia (NBS), and } \\
\text { other institutions subject to minimum reserve system): } \\
\text { Liabilities regardless of currency denominations with positive RRR (currently } 2 \%)^{2} \\
\text {-- Deposits: overnight deposits; time deposits and loans received with agreed maturity up } \\
\text { to } 2 \text { years } \\
\text {-- Deposits redeemable at notice up to } 2 \text { years } \\
\text {-- Debt securities issued except mortgage bonds with agreed maturity up to } 2 \text { years }\end{array}$ \\
\hline $\begin{array}{l}\text { 3. Reserve Computation } \\
\text { Period (CP) }\end{array}$ & 1 day, the last calendar day of each month except December. ${ }^{3}$ \\
\hline $\begin{array}{l}\text { 4. Reserve Maintenance } \\
\text { Period (MP) }\end{array}$ & $\begin{array}{l}1 \text { calendar month, a MP begins on the } 1^{\text {st }} \text { day and ends on the last calendar day of the } 2^{\text {nd }} \\
\text { month after the computation date except the MP in February, e.g. minimum reserves for the } \\
\text { MP of January } 2006 \text { are computed on November 30, 2005. }\end{array}$ \\
\hline 5. Lag & 1month from the CP to the start of the corresponding MP except February. ${ }^{3}$ \\
\hline $\begin{array}{l}\text { 6. Calculation of Required } \\
\text { Reserves (RR) }\end{array}$ & $\begin{array}{l}\text { RR is calculated by multiplying the } 2 \% \text { RRR by the reserve base (sum of reservable } \\
\text { liabilities subject to a positive RRR) of an institution on the computation date. }\end{array}$ \\
\hline $\begin{array}{l}\text { 7. Eligible Assets for Meeting } \\
\text { Reserve Requirement } \\
\text { - Vault Cash (VC) - No } \\
\text { - Reserve Balance (RB) -- } \\
\text { Yes }\end{array}$ & $\begin{array}{l}\text { Vault Cash (VC) - not eligible for satisfying RR } \\
\text { Reserve Balance (RB) - a bank must hold its minimum required reserves in its reserve } \\
\text { account in Slovak koruna with the NBS, except electronic money institutions which may } \\
\text { hold its minimum reserves indirectly through an intermediary } \\
\text { An institution's average of the daily end-of-day balances in its own or intermediary's } \\
\text { reserve accounts in a MP must satisfy its RR. }\end{array}$ \\
\hline $\begin{array}{l}\text { 8. Carry-Over } \\
\text { - RB -- No }\end{array}$ & $\begin{array}{l}\text { A DI is not allowed to carry over any excess reserves or deficiency of its minimum } \\
\text { reserves in one MP to be used or made up in the following MP. }\end{array}$ \\
\hline 9. Remuneration --Yes & $\begin{array}{l}\text { The average of actual daily end-of-day holdings of a bank's minimum reserves in a MP up } \\
\text { to the required amount with the NBS is remunerated at an annual rate of } 1.5 \% \text {. The } \\
\text { remuneration is paid on the second NBS business day following the end of the MP over } \\
\text { which the remuneration was earned. Excess reserves are not remunerated. } \\
\mathrm{R}_{\mathrm{t}}=\left(\mathrm{H}_{\mathrm{t}} \cdot \mathrm{n}_{\mathrm{t}} \cdot \mathrm{r}_{\mathrm{t}}\right) /(100.360) \text {; where: } \\
\mathrm{R}_{\mathrm{t}}=\text { the remuneration to be paid on holdings of RR for MP } \mathrm{t} \text {; } \\
\mathrm{H}_{\mathrm{t}}=\text { average of daily RR holdings for the MP } \mathrm{t} \text {; } \\
\mathrm{n}_{\mathrm{t}}=\text { the number of calendar days in the MP } \mathrm{t} \text {; } \\
\mathrm{r}_{\mathrm{t}}=\text { rate of remuneration (1.5\%). }\end{array}$ \\
\hline 10. Penalty -- Yes & $\begin{array}{l}\text { NBS assesses penalty interest on the average of deficient amounts in a MP at a rate equal to } \\
5 \text { percentage points above the interest rate on overnight refinancing operations of the NBS } \\
\text { prevailing on the last day of the MP for the number of calendar days in the MP. }\end{array}$ \\
\hline $\begin{array}{l}\text { 11. Required Clearing } \\
\text { Balance (RCB) -- No }\end{array}$ & \\
\hline
\end{tabular}

1. The institutions subject to reserve requirements are: banks, branch offices of foreign banks, home savings banks, and electronic money institutions

2. Electronic money institutions are subject to the $2 \%$ RRR when their outstanding value of the electronic money issued reaches the amount of EUR 5,000.

3. The minimum required reserves to be maintained in February are computed based on the reservable liabilities as of November 30 of the previous year, instead of December 31 of that year. 
Table 9

Main Features of the Minimum Reserve Requirements in Switzerland ${ }^{1}$

\begin{tabular}{|c|c|}
\hline Feature & Description \\
\hline 1. RR Type & Lagged RR (LRR) \\
\hline $\begin{array}{l}\text { 2. Reservable Liabilities and } \\
\text { Required Reserve Ratios } \\
\text { (RRR) }\end{array}$ & $\begin{array}{l}\text { Reservable Liability (excluding those arising from repo transactions with the Swiss } \\
\text { National Bank (SNB) and banks and those denominated in foreign currencies): } \\
\text { Liabilities denominated in Swiss franc subject to RR (RRR is currently at 2.5\%) } \\
\text {-- Liabilities vis-à-vis banks payable on sight or maturing within } 3 \text { months if these banks } \\
\text { are not themselves subject to minimum reserve requirements; } \\
\text {-- 20\% of liabilities vis-à-vis customers in the form of savings and investments } \\
\text { (excluding tied-up pension monies); } \\
\text {-- Other liabilities vis-à-vis customers payable on sight or maturing within } 3 \text { months; } \\
\text {-- Median-term bank-issued notes maturing within } 3 \text { months; } \\
\text {-- Money market paper maturing within } 3 \text { months. }\end{array}$ \\
\hline $\begin{array}{l}\text { 3. Reserve Computation } \\
\text { Period (CP) }\end{array}$ & $\begin{array}{l}3 \text { days, the end-dates of the three consecutive calendar months preceding the end of the } \\
\text { corresponding maintenance period. Reserve base is the average of total reservable } \\
\text { liabilities on each of the } 3 \text { computation dates. }\end{array}$ \\
\hline $\begin{array}{l}\text { 4. Reserve Maintenance } \\
\text { Period (MP) }\end{array}$ & $\begin{array}{l}\text { Each MP starts on the } 20^{\text {th }} \text { of each calendar month following the end of CP and ends on the } \\
19^{\text {th }} \text { day of the following month. }\end{array}$ \\
\hline 5. Lag & $\begin{array}{l}20 \text { days from the end of the CP (the } 3^{\text {rd }} \text { computation date) to the start of the } \\
\text { corresponding MP. }\end{array}$ \\
\hline $\begin{array}{l}\text { 6. Calculation of Required } \\
\text { Reserves (RR) } \\
\end{array}$ & $\begin{array}{l}\text { RR is calculated as } 2.5 \% \text { of the reserve base (average of the total reserve liabilities subject } \\
\text { to a positive RRR on each of the } 3 \text { computation dates) of an institution. }\end{array}$ \\
\hline $\begin{array}{l}\text { 7. Eligible Assets for Meeting } \\
\text { Reserve Requirement } \\
\text { - Vault Cash (VC) - Yes } \\
\text { - Reserve Balance (RB) -- } \\
\text { Yes }\end{array}$ & $\begin{array}{l}\text { Vault Cash (VC) denominated in Swiss franc -- eligible for satisfying RR up to } 100 \% \text {. } \\
\text { Reserve Balance (RB) - sight deposits with the SNB is used to satisfy the portion of RR } \\
\text { above the applied VC. } \\
\text { An institution's average of the sum of its daily end-of-day balances of VC and sight } \\
\text { deposits with the SNB in a MP must satisfy its RR. }\end{array}$ \\
\hline $\begin{array}{l}\text { 8. Carry-Over } \\
\text { - RB -- No }\end{array}$ & $\begin{array}{l}\text { A DI is not allowed to carry over any excess reserves or deficiency of its minimum } \\
\text { reserves in one MP to be used or made up in the following MP. }\end{array}$ \\
\hline 9. Remuneration --No & The SNB does not pay interest on minimum reserves. \\
\hline 10. Penalty -- Yes & $\begin{array}{l}\text { Penalty payments levied on the shortfall of the average of the minimum reserve } \\
\text { requirement in a MP for a term of } 30 \text { days at a rate equal to } 3 \text { percentage points above the } \\
\text { one-month Libor for Swiss deposits. }\end{array}$ \\
\hline $\begin{array}{l}\text { 11. Required Clearing } \\
\text { Balance (RCB) -- No }\end{array}$ & \\
\hline
\end{tabular}

1. Institutions subject to minimum reserve requirements: solely banks, and bank groups with collective liquidity management. 


\section{Table 10}

\section{Main Features of Reserve Requirements in Turkey ${ }^{1}$}

\begin{tabular}{|c|c|}
\hline Feature & Description \\
\hline 1. RR Type & Lagged RR (LRR) \\
\hline $\begin{array}{l}\text { 2. Reservable Liabilities and } \\
\text { Required Reserve Ratios } \\
\text { (RRR) }\end{array}$ & $\begin{array}{l}\text { Reservable Liability denominated in Turkish currency are subject to the RRR } \\
\text { different from those denominated in foreign currencies (excluding those vis-à-vis the } \\
\text { Central Bank of the Republic of Turkey (CBRT), Turkish Treasury, and other banks) }{ }^{2} \\
\text { Reserve base is the sum of the total domestic liabilities denominated in Turkish currency } \\
\text { (or foreign currencies) after netting out the deductible items, and the deposits/participation } \\
\text { funds denominated in Turkish currency (or foreign currencies) collected in Turkey on } \\
\text { behalf of their branches abroad. } \\
\text { RRR - } 6 \% \text { for Turkish currency liabilities and } 11 \% \text { for foreign exchange liabilities. }\end{array}$ \\
\hline $\begin{array}{l}\text { 3. Reserve Computation } \\
\text { Period (CP) } \\
\end{array}$ & $\begin{array}{l}\text { A single day, each CP is on Friday in every two weeks. It is also the first day of the MP } \\
\text { associated with the previous reserve computation date. }\end{array}$ \\
\hline $\begin{array}{l}\text { 4. Reserve Maintenance } \\
\text { Period (MP) }\end{array}$ & $\begin{array}{l}2 \text { weeks, each MP lags } 14 \text { days from its associated CP, i.e. each MP starts on the Friday of } \\
\text { the next CP and ends on the second Thursday ( } 14 \text { days later). }\end{array}$ \\
\hline 5. Lag & 14 days lag (from the start of a CP to the star of the MP). \\
\hline $\begin{array}{l}\text { 6. Calculation of Required } \\
\text { Reserves (RR) }\end{array}$ & $\begin{array}{l}\text { RR is calculated as the sum of the two items - (1) } 6 \% \text { of the average balance of a bank's } \\
\text { reserve liabilities denominated in Turkish currency, and (2) } 11 \% \text { of the average balance of } \\
\text { the banks' foreign-currency reservable liabilities on the computation date. }\end{array}$ \\
\hline $\begin{array}{l}\text { 7. Eligible Assets for Meeting } \\
\text { Reserve Requirement } \\
\text { - Vault Cash (VC) - No } \\
\text { - Reserve Balance (RB) -- } \\
\text { Yes }\end{array}$ & $\begin{array}{l}\text { Vault Cash (VC) - not eligible for satisfying RR. } \\
\text { Reserve Balance (RB) - a bank must hold its required reserves, in New Turkish Lira for } \\
\text { the Turkish liabilities and in U.S. dollar and/or euro for foreign exchange liabilities, in its } \\
\text { account (for reserves and settlement purposes) with CBRT. Required reserves for the 8- } \\
\text { percent portion of the } 11 \text { percent RRR for foreign exchange liabilities are maintained in } \\
\text { blocked accounts. } \\
\text { An institution's averages of the daily end-of-day balances in its reserve accounts for } \\
\text { domestic currency in a MP must satisfy its RR. The average provision is also applied to } \\
\text { required reserves for the 3-percent portion of the 11-percent RRR for foreign exchange } \\
\text { liabilities. }\end{array}$ \\
\hline $\begin{array}{l}\text { 8. Carry-Over } \\
\text { - RB -- No }\end{array}$ & $\begin{array}{l}\text { A DI is not allowed to carry over any excess reserves or deficiency of its minimum } \\
\text { reserves in one MP to be used or made up in the following MP. }\end{array}$ \\
\hline 9. Remuneration --Yes & $\begin{array}{l}\text { CBRT pays interest on the average balance of a MP of Turkish required reserves at a rate } \\
\text { equal to } 75 \% \text { of overnight borrowing interest rate of CBRT (remuneration rate is } 13.12 \% \\
\text { as of } 9 / 10 / 2006 \text { ). The remuneration interest rate on foreign exchange required reserves are } \\
\text { determined weekly, and equivalent to the rate on } 2 \text {-day notice foreign exchange deposits } \\
\text { that banks hold as free deposits with CBRT (remuneration rate is } 2.540 \% \text { for U.S. dollar } \\
\text { and } 1.335 \% \text { for euro, as of } 9 / 10 / 2006 \text { ). (It is almost half of market interest rates such as } \\
\text { LIBOR or FIBOR). The remunerations are accrued at the end of each calendar quarter. }\end{array}$ \\
\hline 10. Penalty -- Yes & $\begin{array}{l}\text { If a bank fails to comply with reserve requirements on time or with insufficient amounts, it } \\
\text { is required to hold interest-free deposits in blocked accounts with CBRT in the amount of } \\
\text { double the deficient portion of Turkish currency required reserves in term of New Turkish } \\
\text { Lira, three-fold the deficient portion of the foreign exchange required reserves in term of } \\
\text { U.S. dollar, taking into account the periods of deficiency. Otherwise, the bank is assessed } \\
\text { with interest payments on the average deficient amount in the MP at a rate equal to } 150 \% \\
\text { of the maximum overnight lending rate announced by CBRT on the last day of the MP. }\end{array}$ \\
\hline $\begin{array}{l}\text { 11. Required Clearing } \\
\text { Balance (RCB) -- No }\end{array}$ & \\
\hline
\end{tabular}

1. Institutions subject to minimum reserve requirements: banks that are founded in Turkey or operate in Turkey through their branches, including those that operate in free trade zones.

Deductible items are, in addition to liabilities to CBRT, Turkish Treasury, and other banks, equity capital, provisions, funds obtained from repo transactions, credits obtained from abroad with Treasury guaranty, and liabilities to the Head office and branches abroad (net) which are up to the amount of deposits/participation funds collected in Turkey on behalf of their branches abroad. 


\section{Table 11}

\section{Main Features of the Reserve Scheme in the United Kingdom}

\begin{tabular}{|c|c|}
\hline $\begin{array}{r}\text { Feature } \\
\end{array}$ & Description \\
\hline 1. Reserve Account Type & $\begin{array}{l}\text { - Participation in the reserve scheme is voluntary except for CHAPS sterling and } \\
\text { CREST sterling settlement banks. } \\
\text { - Participants specify their individual reserve targets at least } 2 \text { business days } \\
\text { before the start of each maintenance period (MP). }\end{array}$ \\
\hline 2. Reservable Liabilities & $\begin{array}{l}\text { Eligible reservable liability denominated in sterling (excluding deposits made by the } \\
\text { Bank of England (BOE) and repos with BOE ): } \\
\text {--Deposits with original maturity up to } 2 \text { years (sight deposits; time deposits; and CDs). } \\
\text {--Cash loaded smart cards } \\
\text {--Commercial paper and issues of other paper with original maturity up to } 5 \text { years } \\
\text {--Liabilities under sale and repurchase agreements } \\
\text {--Items in suspense including all credit balances relating to customers' funds, but not in } \\
\text { customers' names and awaiting transfer or investment, etc. } \\
\text {--Credit items in the course of transmission }\end{array}$ \\
\hline $\begin{array}{l}\text { 3. Reserve Target } \\
\text { Specification }\end{array}$ & $\begin{array}{l}\text { Participants are free to choose their reserve targets which are set in multiples of } £ 10 \text { million } \\
\text { and bonded by zero and the ceilings (see item } 6 \text { ). Reserve targets can be changed from one } \\
\text { MP to the next with no constraints on the size of changes but limited by target ceilings. }\end{array}$ \\
\hline $\begin{array}{l}\text { 4. Reserve Maintenance } \\
\text { Period (MP) }\end{array}$ & $\begin{array}{l}\text { Each MP normally starts on the policy decision day of the Monetary Policy Committee } \\
\text { (MPC) and ends on the day before the next month’s MPC policy announcement (normally } \\
\text { a Thursday and a Wednesday respectively). Thus, some MPs are four weeks and some } \\
\text { five weeks. }\end{array}$ \\
\hline 5. Lag & A least two working days between setting the reserve target and the start of a MP. \\
\hline $\begin{array}{l}\text { 6. Calculation of Reserve } \\
\text { Target Ceiling }\end{array}$ & $\begin{array}{l}\text { Ceilings are calculated twice a year, in May and November with new ceilings effective } \\
\text { from the MPs starting in June and December. Ceilings are equal to the greater of } £ 1 \text { billion } \\
\text { or } 2 \% \text { of the averages of the sterling eligible liabilities over the six months to April and } \\
\text { October. }\end{array}$ \\
\hline $\begin{array}{l}\text { 7. Eligible Asset for Reserve } \\
\text { Account -- Reserve Balance } \\
\text { (RB) }\end{array}$ & $\begin{array}{l}\text { Vault Cash (VC) - not eligible for satisfying RR } \\
\text { Reserve Balance (RB) - participants must hold their reserves in their reserve or settlement } \\
\text { accounts at the BOE. RB can be varied freely to meet day-to-day liquidity needs, but the } \\
\text { average of daily end-of-day RBs in each MP must not fall outside the target band (equal to } \\
+/-1 \% \text { of the point target declared) to avoid penalty. }\end{array}$ \\
\hline $\begin{array}{l}\text { 8. Carry-Over } \\
\text { - RB -- No }\end{array}$ & $\begin{array}{l}\text { A participant is not allowed to carry over any excess reserves or deficiency of its reserves } \\
\text { in one MP to be used or made up in the following MP. }\end{array}$ \\
\hline 9. Remuneration --Yes & $\begin{array}{l}\text { - Actual average reserves up to the top of the target band are remunerated at the MPC's } \\
\text { official rate. } \\
\text { - Excess reserves above the tops of the target bands are not remunerated. }{ }^{3} \\
\text { - If average reserves are lower than the target band, the actual average balance is } \\
\text { remunerated at the MPC's official rate. } \\
\text { - Interest is paid on the basis of } 365 \text { days a year and paid up to the last day of the MP. } \\
\text { Interest is credited directly to the participant's reserve account on the first day of the } \\
\text { following MP. }\end{array}$ \\
\hline 10. Penalty -- Yes & $\begin{array}{l}\text { - Excess reserves above the tops of target bands or shortfalls of reserves below the } \\
\text { bottoms of the bands are charged at the MPC's official rate and deducted from the } \\
\text { interest paid. }{ }^{4} \\
\text { - CHAPS or CREST settlement banks' overdrafts on individual days during the MP are } \\
\text { charged twice the MPC's official rate and the charge is deducted from the account the } \\
\text { next working day. }\end{array}$ \\
\hline
\end{tabular}

1. CHAPS (Clearing House Automated Payment System) is the sterling high-value payment system, providing members with Real Time Gross Settlement (RTGS) of transferring central bank money across accounts at the BOE.

2. CREST is the UK securities settlement system, providing a Delivery versus Payment (DvP) settlement service for UK securities with associated sterling payments made in central bank money across RTGS accounts at the BOE.

3. The BOE aims for stable overnight interbank rates and zero surplus liquidity in the banking system at macro level every day. When participants hold excess reserves, they may become "lock-in' before the end of the MP. ('Locking in' means that it is no longer possible to restore the average balance within the target band even if the account balance is reduced to zero for the rest of the period.) The BOE has to 'recycle these excess reserves back to the market in its open market operations to enable all other participants to meet their reserve targets. 
Table 12

Main Features of the Reserve Requirement System in the United States

\begin{tabular}{|c|c|c|}
\hline Feature & \multicolumn{2}{|l|}{ Description } \\
\hline 1. RR Type & \multicolumn{2}{|l|}{ Lagged RR (LRR) } \\
\hline \multirow{2}{*}{$\begin{array}{l}\text { 2. Reservable Liabilities and } \\
\text { Required Reserve Ratios } \\
\text { (RRR) }\end{array}$} & Reservable Liability & $\begin{array}{c}\text { RRR } \\
\text { (\%) }\end{array}$ \\
\hline & 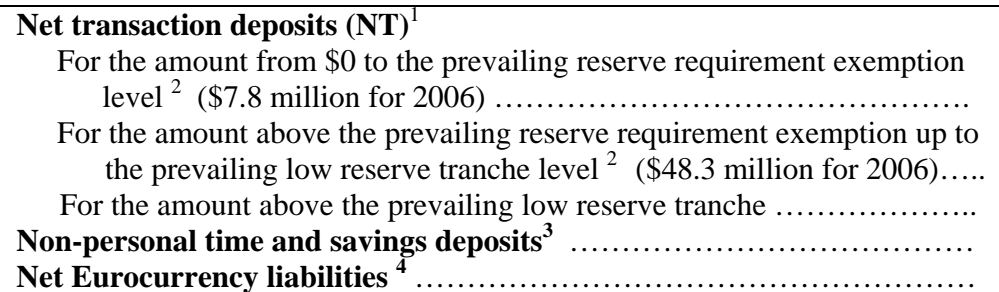 & $\begin{array}{c}3 \\
10 \\
0 \\
0\end{array}$ \\
\hline $\begin{array}{l}\text { 3. Reserve Computation } \\
\text { Period (CP) } 5 \\
\text { - End (day) -- Monday }\end{array}$ & \multicolumn{2}{|c|}{$\begin{array}{l}\text { - For weekly deposit reporters - } 2 \text { weeks, beginning every other Tuesday and ending on } \\
\text { the second Monday. } \\
\text { - For quarterly deposit reporter - } 1 \text { week, beginning on the third Tuesday of the quarter- } \\
\text { end month and ending the following Monday. }\end{array}$} \\
\hline $\begin{array}{l}\text { 4. Reserve Maintenance } \\
\text { Period (MP) }{ }^{5} \\
\text { - End (day) -- Wednesday }\end{array}$ & \multicolumn{2}{|c|}{$\begin{array}{l}\text { - For weekly deposit reporters }-2 \text { weeks, beginning on the } 31^{\text {st }} \text { day (Thursday) following } \\
\text { the start of the associated CP and ending on the second Wednesday. } \\
\text { - For quarterly deposit reporters }-1 \text { week, beginning on the } 31^{\text {st }} \text { day (Thursday) following } \\
\text { the start of the associated CP and ending the following Wednesday. }{ }^{6}\end{array}$} \\
\hline 5. Lag & \multicolumn{2}{|c|}{ A lag of 30 days from the start of a CP to start of the corresponding MP. } \\
\hline $\begin{array}{l}\text { 6. Calculation of } \mathbf{R R} \\
\text { - Reserve Base - daily } \\
\text { average of reservable } \\
\text { liabilities in a CP } \\
\text { - } \mathbf{R R R}-3 \text { tier rates in item } 2\end{array}$ & \multicolumn{2}{|c|}{$\begin{array}{l}\text { RR is equal to the sum of the products of each of the three RRRs (item } 2) \text { times the } \\
\text { corresponding tier of the average of a depository institution’s (DI’s) daily NT deposit } \\
\text { balances in a CP. For example, a DI with an average of daily net transaction deposits of } \\
\$ 100 \text { million in a CP has RR equal to } \$ 6.385 \text { million as calculated below: } \\
\text { Required reserves }=(\$ 7.8 \text { million } \times 0.0)+[(\$ 48.3 \text { million }-\$ 7.8 \text { million }) \times 0.03] \\
\qquad+[(\$ 100.0 \text { million }-\$ 48.3 \text { million }) \times 0.10] .\end{array}$} \\
\hline $\begin{array}{l}\text { 7. Eligible Assets for Meeting } \\
\text { Reserve Requirement } \\
\text { - Vault Cash (VC) - Yes } \\
\text { - Reserve Balance (RB) -- } \\
\text { Yes }\end{array}$ & \multicolumn{2}{|c|}{$\begin{array}{l}\text { Vault Cash (VC) -- up to } 100 \% \text { of RR } \\
\text { Reserve Balance (RB) -- If VC is insufficient to meet RR in a MP, the remaining RR, } \\
\text { called reserve balance requirement, must be satisfied by RB, which is the deposit balance } \\
\text { held by a DI or its correspondent at its FRB. } \\
\text { Daily RBs of a DI may be above or below its RB requirement, but not negative, and } \\
\text { average of daily RBs plus VC in a MP must satisfy its RR. }\end{array}$} \\
\hline $\begin{array}{l}\text { 8. Carry-Over } \\
\text { - VC -- No } \\
\text { - RB -- Yes }\end{array}$ & \multicolumn{2}{|c|}{$\begin{array}{l}\text { A DI that has a reserve balance requirement is allowed to carry over some excess or } \\
\text { deficiency of required reserve balances in one MP to be used or made up only in the } \\
\text { following MP. The maximum allowable reserve balance carry-over is equal to the greater } \\
\text { of } \$ 50,000 \text { or four percent of the total requirement (reserve requirement plus RCB, if any), } \\
\text { less clearing balance allowance, if applicable (see item } 11 \text { below for detail). }\end{array}$} \\
\hline 9. Remuneration -- No & \multicolumn{2}{|c|}{ Reserve balances are not remunerated by the FR banks. $^{7}$} \\
\hline 10. Penalty & \multicolumn{2}{|c|}{$\begin{array}{l}\text { A charge on the shortfall of the average of daily reserve balances in a MP is assessed at a } \\
\text { rate equal to } 1 \% \text { (annual rate) above the primary credit rate (i.e. } 2 \% \text { over the target } \\
\text { overnight rate, as the primary credit rate is } 1 \% \text { over the target overnight rate) in effect for } \\
\text { borrowing from the FRB on the first day of the month in which the deficiency occurs. }\end{array}$} \\
\hline $\begin{array}{l}\text { 11. Required Clearing } \\
\text { Balance (RCB) }\end{array}$ & \multicolumn{2}{|c|}{$\begin{array}{l}\text { A RCB is an amount that a DI may contract to maintain at its FRB in addition to its } \\
\text { reserve balance requirement, to protect it from overdrafts. A FRB may impose a clearing } \\
\text { balance requirement if a DI has a history of frequent daylight or overnight overdrafts. The } \\
\text { amount of a RCB must be set before the effective MP and it can be adjusted prior to each } \\
\text { MP. The average of a DI's daily end-of day RCB in a given MP needs to fall within the } \\
\text { clearing balance band around its RCB. The top (bottom) of the clearing balance band is } \\
\text { equal to the clearing balance requirement plus (minus) the clearing balance allowance, } \\
\text { which is equal to the greater of } \$ 25,000 \text { or two percent of the RCB. } \\
\text { The average, up to the top of clearing balance band, of a DI's actual daily end-of-day } \\
\text { clearing balances in a MP generates earnings credits (ECs), which is calculated based on } \\
\text { the prevailing earnings credit rate and two adjustments. }{ }^{8} \text { ECs may be used to offset } \\
\text { charges of eligible FRB services, such as check clearing, and wire transfer of funds and } \\
\text { securities. Excess ECs can be carried over to be applied to future eligible FRB services } \\
\text { incurred in the subsequent } 52 \text { weeks. If not used it is forfeited. ECs are not transferable. } \\
\text { RCBs must be set before the beginning of a MP, and can be adjusted for each MP. }\end{array}$} \\
\hline
\end{tabular}


Footnotes to table 12:

1. Net transaction deposits are equal to total transaction deposits at depository institutions regardless of ownership (consisting of gross demand deposits, ATS accounts, NOW accounts/share drafts, and telephone and preauthorized transfers), plus ineligible acceptances and obligations issued by affiliates maturing in less than seven days, minus CIPC and demand deposit balances due from other depository institutions.

2. The reserve requirement exemption and low reserve tranche amounts are designed to reduce the burden of required reserves for small depository institutions. To adjust for increasing burden over time as deposits grow from year to year, both the exemption and low reserve tranche levels are indexed annually. The newly indexed levels are announced before each year end and are effective in the reserve maintenance period including January 1 of the following year. The change in the reserve exemption level, which can only be positive, is equal to $80 \%$ of the annual (positive) growth rate of total reservable liabilities of all depository institutions from June 30 in the previous year to the most recent June 30. No adjustment to exemption level is made for that year if the growth rate of total reservable liabilities is zero or negative. The adjustment to low reserve tranche, positive or negative, is equal to $80 \%$ of the growth rate of net transaction deposits of all depository institutions from June 30 in the previous year to the most recent June 30 .

3. Non-personal time and savings deposits consist of time deposits and savings deposits held by entities other than individuals and households.

4. Net Eurocurrency liabilities consist of net borrowings (gross liabilities minus gross claims of a depository institution from its own offshore branches and IBF), assets held and acquired from U.S. offices by its own IBF and own offshore branches, credit extended by its own offshore branches to U.S. residents, and gross borrowings from offshore branches of other depository institutions and from certain designed offshore entities.

5. In the U.S., reserve computation periods and the corresponding maintenance periods vary according to the frequency of deposits reporting, which is determined by sizes of depository institutions. Required reserves are calculated based on the average of daily deposit balances in the computation period, and the same formula is used for both weekly and quarterly deposit reporters.

6. The amount of reserves calculated from a given computation period is held for a corresponding maintenance cycle. The maintenance cycle consists of a multi-week sequence of maintenance periods, beginning on the fourth Thursday following the end of that computation period and ending on the fourth Wednesday after the close of the next computation period. A maintenance cycle usually consists of 13 weeks, but on occasion will be 12 or 14 weeks long, depending on the calendar.

7. At present, the Federal Reserve System does not have statutory authority to remunerate depository institutions on required reserve balances and excess reserves. However, on October 13, 2006, the President of the United States signed The Financial Services Regulatory Relief Act of 2006, Pub. L. No. 109-351 (2006), which included the following provision (SEC. 201. Authorization for the Federal Reserve to Pay Interest on Reserves) - "Balances maintained at a Federal Reserve bank by or on behalf of a depository institution may receive earnings to be paid by the Federal Reserve bank at least once each quarter, at a rate or rates not to exceed the general level of short-term interest rates." - with an effective date of October 1, 2011. This same legislation permits the Federal Reserve to reduce reserve requirements, or even eliminate them, with the same effective date.

8. A representation of the formula for calculating earning credits is:

$$
e=b *\left[\left(1-M R R_{R B}\right) * \text { erate }+M R R_{t} * \text { ffrate }\right]
$$

where $e$ is total earnings credits, $b$ is the average end-of-day clearing balance maintained (after application of any as-of adjustments) during the maintenance period, $M R R_{R B}$ is the Reserve Bank's imputed marginal reserve requirement ratio (10\%), erate is the earning credit rate (the rolling 13-week average of the annualized coupon equivalent yield of three-month Treasury bill rate in the secondary market), $M R R_{t}$ is the institution's marginal reserve requirement ratio (0, $3 \%$, or $\left.10 \%\right)$, and ffrate is the average effective federal funds rate over the maintenance period. Prior to January 2004, the earnings credit rate was equal to the effective federal funds rate. 


\section{REFERENCES}

Bank of England, 2005. "The Bank of England's Operations in the Sterling Money Markets: Operating Procedures.” December.

Bank of England, 2006. “The Framework for the Bank of England’s Operations in the Sterling Money Market.” May.

Borio, C. E. V., 1997. “Monetary Policy Operating Procedures in Industrial Countries.” Bank for International Settlements. Working paper No. 40. Basel

Borio, C. E. V., 2000. "Monetary Policy Operating Procedures in the United States, Japan and EMU: A Comparative Assessment”. Bank for International Settlements. Paper prepared for the ECB Conference on "The Operational Framework of the Eurosystem and Financial Market."

Carpenter, S. B. and S. Demiralp, 2006. “Anticipation of Monetary Policy and Open Market Operations.” International Journal of Central Banking, Vol. 2 No. 2. pp 25-63.

Clinton, K., 1997. "Implementation of Monetary Policy in a Regime with Zero Reserve Requirements.” Bank of Canada Working Paper 97-8.

Clouse J. A. and D. W. Elmendorf, 1997. "Decline Required Reserves and the Volatility of the Federal Funds Rate.” Finance and Economics Discussion Series, 1997-30, Federal Reserve Board, Washington, DC.

European Central Bank, 2005. “The Implementation of Monetary Policy in the Euro Area.” General Documentation on Eurosystem Monetary Policy Instruments and Procedures.” February.

Frazer, J., 2004. “Liquidity Management in the New Zealand Banking System.” December. Reserve Bank of New Zealand, Financial Stability Department.

Hall, R. E., 1986. “Optimal Monetary Institutions and Policy.” Chapter 6 in Alternative Monetary Regime.” Edited by C. D. Campbell and W. R. Dougan, 1986.

Hilton, S. 2005. “Trends in Federal Funds Rate Volatility.” Current Issues in Economics and Finance, Vol. 11, No. 7, Federal Reserve Bank of New York, July

Lindsey, D. E., 1986. “The Monetary Regime of the Federal Reserve System.” In: Chapter 5, Alternative Monetary Regime.” Edited by C. D. Campbell and W. R. Dougan, 1986.

Reserve Bank of New Zealand, 2006. "Reform of the Reserve Bank of New Zealand's Liquidity Management Operations.” June

Sellon, G. H. Jr. and S. E. Weiner., 1996. "Monetary Policy Without Reserve Requirements: Analytical Issues.” Economic Review, Fourth Quarter, Federal Reserve Bank of Kansas City. 
Sellon, G. H. Jr. and S. E. Weiner., 1997. "Monetary Policy Without Reserve Requirements: Case Studies and Options for the United States.” Economic Review, Second Quarter, Federal Reserve Bank of Kansas City.

Wallich, H. C., 1984. "Recent Techniques of Monetary Policy.” Economic Review, May, Federal Reserve Bank of Kansas City.

Whitesell, W., 2003. “Tunnels and Reserves in Monetary Policy Implementation.” Finance and Economics Discussion Series, 2003-27, Federal Reserve Board, Washington, DC.

Whitesell, W., 2006. “Interest Rate Corridors and Reserves.” Journal of Monetary Economics, Vol. 53. pp 1177-1195.

Whitesell, W., 2006. “Monetary Policy Implementation Without Average or Rate Corridors.” Finance and Economics Discussion Series, 2006-22, Federal Reserve Board, Washington, DC.

Yacaman, J. M. 2000. “The Implementation of Monetary Policy through the Zero-Average Reserve Requirement System: the Mexican Case.” The Bank of Mexico. 